\title{
Plate kinematics in the Cantabrian domain of the Pyrenean orogen
}

\author{
S. Tavani \\ Dipartimento di Scienze della Terra, Università Federico II, Naples, Italy \\ Correspondence to: S. Tavani (stefano.tavani@unina.it)
}

Received: 23 March 2012 - Published in Solid Earth Discuss.: 3 April 2012

Revised: 12 July 2012 - Accepted: 24 July 2012 - Published: 3 September 2012

\begin{abstract}
The Cantabrian domain represents the western portion of the Pyrenean orogen, in the area where the Iberian continental lithosphere was subducted toward the north underneath the transitional to oceanic lithosphere of the Bay of Biscay. There, the about $100 \mathrm{~km}$ of orogenic convergence have been mostly accommodated in the northern portion of the orogen (i.e. the retro wedge) developed in the Bay of Biscay abyssal plain, while only crustal-scale folding with limited internal deformation occurred in the Cantabrian southern wedge (pro-wedge). Integrated meso- and macrostructural analyses and a reappraisal of available information from the transitional area between the Pyrenean and Cantabrian domains are presented in this work, allowing to set geometric and kinematic constraints on the entire Meso-Cenozoic history of the northern portion of the Iberian Plate, including subduction initiation and evolution in the western portion of the Pyrenean orogen.

The structural record of the Late Jurassic to Early Cretaceous deformation stage, which was associated with rifting and seafloor spreading in the Bay of Biscay, indicates a ridge perpendicular (NNE-SSW oriented) extension, with no evidence of relevant strike-slip components during rifting. A Cenozoic NNW-SSE oriented shortening stage followed, related to the limited (about $100 \mathrm{~km}$ ) north-directed subduction of the Iberian continental lithosphere underneath the transitional to oceanic lithosphere of the Bay of Biscay. Subduction led to the formation of the poorlydeveloped Cantabrian pro-wedge, which is laterally juxtaposed to the well-developed Pyrenean pro-wedge to the east. During this convergence stage, the structural framework in the Cantabrian pro-wedge, and particularly along its transition with the Pyrenean wedge to the east, was severely complicated by the reactivation of Paleozoic and Mesozoic inherited structures.
\end{abstract}

Data presented in this work fully support the development of the Cantabrian Mountains as related to indentation and consequent thickening of the Bay of Biscay transitional lower crust during north-directed subduction of Iberian continental lithosphere. In essence, the Cantabrian pro-wedge is a lithospheric south-verging fault-propagation anticline developing above the subduction plane. The structural record in the area indicates that a lithospheric fault-propagation folding stage was predated, during the very early stages of orogenic shortening, by the development of a lithospheric-scale open syncline overlying the nucleation point of lithosphere sinking. Such a syncline is today partially preserved and represents one of the few natural examples of subduction initiation.

\section{Introduction}

The E-W trending Pyrenean orogen represents the boundary between the Iberian and Eurasian plates and extends for more than $1000 \mathrm{~km}$ from the Mediterranean Sea to the Atlantic Ocean (Muñoz, 2002). It formed in Late Cretaceous to Cenozoic age due to the limited (i.e. $100-150 \mathrm{~km}$ ) subduction of the Iberian Plate underneath the Eurasian one, which caused the inversion of a Mesozoic rift system to develop during the opening of the Bay of Biscay (Fig. 1a) (e.g. Choukroune et al., 1989; Roure et al., 1989; Muñoz, 1992; Pulgar et al., 1996; Teixell, 1998; Gallastegui, 2000; Vergés et al., 1995, 2002; Pedreira et al., 2007; Jammes et al., 2009). To the east, the Pyrenean arm of the Mesozoic Bay of Biscay-Pyrenean rift system has been sandwiched between the subducting Iberian Plate and the overriding Eurasian one (e.g. Choukroune et al., 1989; Muñoz, 1992; Teixell, 1998; Pedreira et al., 2007; Roca et al., 2011), which resulted in the development of a doubly vergent orogen. In the 

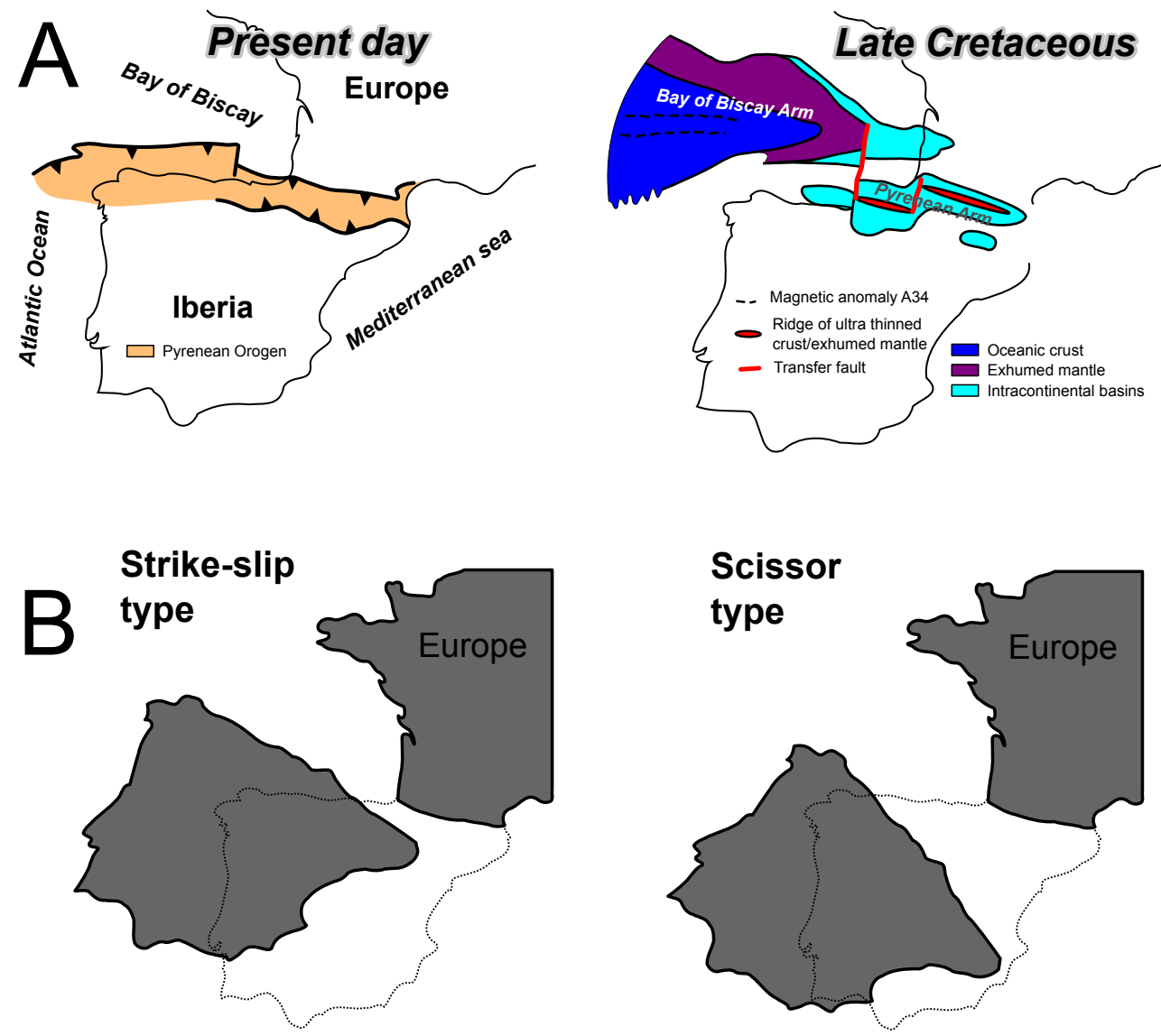

Fig. 1. (A) Present-day and reconstructed Late Cretaceous tectonic sketch map of the Iberia-Eurasia boundary. (B) Paleokinematic reconstruction of Iberia with fixed Eurasia at $118 \mathrm{My}$ (chron M0) according to the strike-slip and scissor type opening models (Modified from Jammes et al., 2009). Dotted lines indicate the present-day shoreline of Iberia.

western portion of the Pyrenean orogen, hereinafter named Cantabrian domain, convergence involved the deformation of the southern passive margin of the Mesozoic rift system (Fig. 1a). There, the southern wedge of the orogen is poorly developed (e.g. Alonso et al., 1996; Pulgar et al., 1996; Gallastegui, 2000; Tavani et al., 2011a) and convergence has been almost entirely accommodated by the development of a northern wedge overlying the transitional to oceanic crust of the Bay of Biscay. These features of the Cantabrian domain, which together with the limited amount of subduction make the area a strongly atypical subduction zone, have suggested south-directed subduction of the oceanic lithosphere of the Bay of Biscay underneath the Iberian continental lithosphere (e.g. Boillot et al., 1979), which was in agreement with a nucleation of the subduction zone by collapse of a passive margin (e.g. Wilson, 1966). Indeed, the conviction that Iberia represented the overriding plate in the western portion of the Pyrenean orogen lasted up until the 1990s, when the ESCIN-2 deep seismic profile, which crosses the central portion of the Cantabrian domain, unequivocally revealed a reverse framework, with subduction of many tens of $\mathrm{km}$ of Iberian continental lithosphere underneath the transitional to oceanic lithosphere of the Bay of Biscay (e.g. Pulgar et al., 1995, 1996; Alonso et al., 1996). The drastic alongstrike change in the style of deformation between the western and eastern portions of the of the Pyrenean orogen, however, is confined to the upper part of the crust. Both Moho and top of the lower crust of the subducting Iberian Plate, in fact, experience negligible variations across the two domains (e.g. Pedreira et al., 2007), and the subducting Iberian lithosphere can be followed at least until the northwestern corner of the Iberian Peninsula (Gallastegui, 2000), where the amount of convergence was less than $40 \mathrm{~km}$ (Alvarez-Marrón et al., 1997). The absence of large-displacement thrusts in the onshore portion of the Cantabrian domain, makes that area one of the few sites in the world where mechanisms operating during initiation of subduction can be easily and directly inferred from the observations of poorly reworked structural and stratigraphic features, although these mechanisms have operated within an atypical subduction zone. A meso- and macrostructural study was carried out in the southern portion of the Cantabrian domain and along its transition to the 
Pyrenean doubly vergent domain, in order to provide insights about deformation processes, stress directions and role of inherited structures during initiation and evolution of Pyrenean orogeny in the Cantabrian domain.

The fact that data presented in this work have been collected along a wide area of the Iberian-European plate boundary requires the clarification of the kinematic framework of Iberia, and in particular about the evolution of its northern margin, which is still matter of debate. Iberia has attracted the curiosity of the geodynamics community since the dawn of plate tectonics, due to the availability of seafloor magnetic anomalies in the Atlantic Ocean and in the Bay of Biscay, which allowed reconstructing the motion of this micro-plate, and due to the possibility of verifying plate tectonics hypotheses in the well-exposed and small-sized Pyrenean orogen. Most of the works published until recent years have shared the hard task of fitting seafloor magnetic anomalies (e.g. Srivastava et al., 1990; Rosenbaum et al., 2002), paleomagnetic (e.g. Van der Voo, 1969) and geological data (e.g. Le Pichon et al., 1970; Choukroune et al., 1989; Roure et al., 1989; Muñoz, 1992; Pulgar et al., 1996; Teixell, 1998). In this sense, it is almost commonly accepted that (1) until Jurassic Iberia and Europe were attached, (2) their separation implied breakup and spreading in the Bay of Biscay, about $35^{\circ}$ counter-clockwise rotation of Iberia with respect to Europe, and left-lateral movements between the two plates. (3) Convergence started in Late Cretaceous. In detail, however, significant differences exist between the different plate kinematic reconstructions, also because uncertainties about the Mesozoic plate configuration of the western Mediterranean area exist (e.g. Capitanio and Goes, 2006), which does not allow to fully constrain the Mesozoic position of Iberia. Two plate-kinematic end-member solutions, both of them based on the study of seafloor magnetic anomalies pattern in the Atlantic Ocean and in the Bay of Biscay, have been classically used to describe the Mesozoic motion of Iberia (for a recent review, see Vissers and Meijer, 2012) and, in particular, the opening of the Bay of Biscay (Fig. 1b). The strike-slip opening model (e.g. Olivet, 1996) assumes that the present-day shape of the Bay of Biscay is mostly related to left-lateral strike-slip movements between Europe and Iberia, which would have started to occur in Aptian-Albian times. This reconstruction, however, contrasts with mesostructural data collected in many intracontinental basins that formed part of the Bay of Biscay-Pyrenean rift system, and which are today exposed in the western (e.g. Tavani and Muñoz, 2012) and eastern portion of the Pyrenean orogen (Tavani et al., 2011b). The alternative scissor-type opening model (e.g. Srivastava et al., 2000; Rosenbaum et al., 2002; Sibuet et al., 2004) predicts about $600 \mathrm{~km}$ of Mesozoic extension and a similar value of shortening in the eastern portion of the Pyrenean orogen. These values are incompatible with the amount of shortening in that area, which ranges from $80 \mathrm{~km}$ (Teixell, 1998) to $120 \mathrm{~km}$ (Vergés et al., 1995), up to a maximum of about $160 \mathrm{~km}$ in the central portion of the Pyrenees (Muñoz,
1992; Beaumont et al., 2000). Differences in the cumulative amount of shortening reduce when considering only the postSantonian seafloor magnetic anomalies (e.g. Rosenbaum et al., 2002). However, this does not imply the absence of discrepancies. In fact, convergence directions inferred from the interpretation of magnetic anomalies are characterised by geologically undetected left-lateral and right-lateral transpressive components during Late Cretaceous and Cenozoic, respectively. With increasing the amount of data, incompatibilities have become increasingly evident. Jammes et al. (2009) made explicit the difficulty of reconciling geology with models based on the interpretation of seafloor magnetic anomalies, and proposed a reconstruction where doubtful (i.e. probably not associated with newly formed oceanic crust) and geologically inconsistent magnetic anomalies are rejected. In essence, Jammes et al. (2009) made the simple consideration that seafloor spreading was only part of the Mesozoic breakup and spreading process, as an important role in the Mesozoic motion of Iberia was played by the exhumed continental mantle, which is exposed in the Pyrenean Mountain Range (e.g. Lagabrielle et al., 2010), and surrounds the oceanic crust of the North Atlantic and of the Bay of Biscay (e.g. Boillot et al., 1987; Sibuet et al., 2007). The result is a reconstruction consistent with a belt perpendicular N-S oriented convergence postdating an almost ridge perpendicular extensional to transtensional stage, thus fitting the geology of the eastern portion of the Pyrenean orogen and of the Bay of Biscay. In line with this approach, data presented in this work provide highly detailed additional evidence of an about N-S oriented (i.e. belt-perpendicular) Pyrenean convergence, making explicit the inconsistency of significant belt-parallel strike-slip components during convergence, and a ridge-perpendicular, NNE-SSW oriented, extension during opening of the Bay of Biscay.

\section{Geological outline}

\subsection{The crustal-scale architecture}

The study area is located at the transition between two distinct domains of the Pyrenean doubly vergent orogen (Fig. 2), which developed in Late Cretaceous to Cenozoic age due to the subduction of the Iberian Plate underneath the Eurasian one (Choukroune et al., 1989; Roure et al., 1989; Muñoz, 1992; Vergés et al., 1995, 2002; Pulgar et al., 1996; Teixell, 1998; Gallastegui, 2000; Pedreira et al., 2007). To the east, in the Pyrenean domain, the far-travelled frontal structures of the south-verging portion of the orogen are characterised by a thin-skin style of deformation (e.g. Choukroune et al., 1989; Muñoz, 1992; Teixell, 1998; Pedreira et al., 2007) (Profiles P1 and P2 of Fig. 2). Conversely, the western Cantabrian domain of the Pyrenean orogen is characterised by a thick-skin style of deformation also in its southernmost frontal portion (Profiles P3 of Fig. 2) (Alonso et al., 1996; 

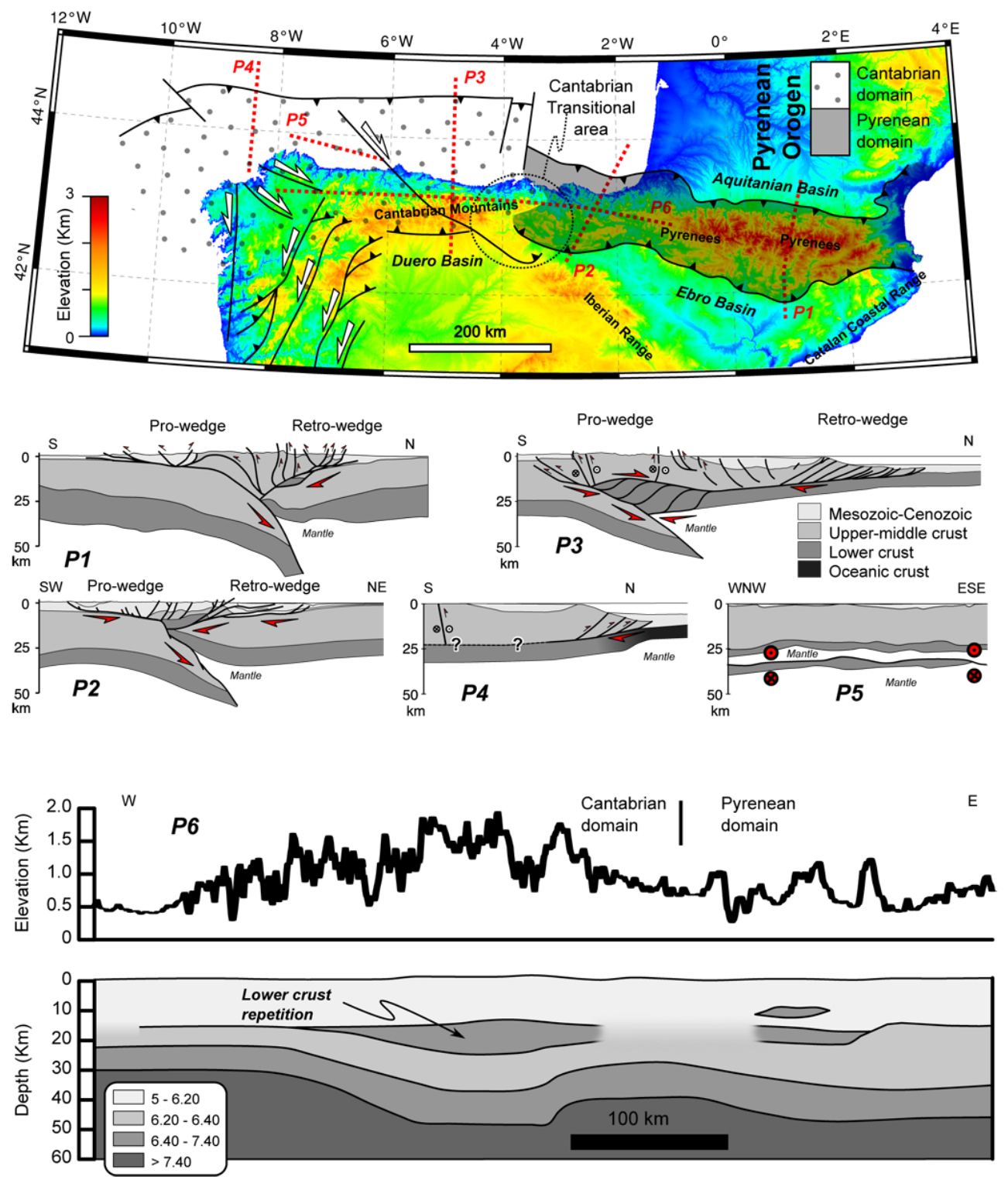

Fig. 2. Elevation map with main faults of the Iberia-Eurasia collisional margin and orogenic domains marked and crustal-scale cross sections. P1: geological cross section across the Pyrenees (after Muñoz, 1992); P2: geological cross section across the Basque Pyrenees (after Pedreira et al., 2007); P3: geological cross section across the Cantabrian Mountains (modified from Gallastegui, 2000); P4: geological cross section across the western termination of the Cantabrian domain (modified from Alvarez-Marrón et al., 1997). P5: geological cross section along the Cantabrian shelf (modified from Ayarza et al., 1998). P6: P-wave velocity-depth model along the Cantabrian Mountains and the western portion of the Basque Pyrenees (modified from Pedreira et al., 2007), with corresponding topographic elevation along the same profile.

Pulgar et al., 1996; Gallastegui, 2000), which accommodated only for few kilometres of N-S oriented shortening (Tavani et al., 2011a). In this western domain, most of the convergence was accommodated in the north-verging portion of the orogen (Gallastegui, 2000; Pedreira et al., 2007), where the amount of Cenozoic shortening was about $90 \mathrm{~km}$ (Gallastegui et al., 2002). Such an anomalous shortening repartition between pro- and retro-wedge in the Cantabrian domain is particularly evident in its western termination, toward which the southern foreland basin (i.e. the Duero Basin) progressively disappears, and contractional structures mostly include strike-slip faults oriented consistently with a roughly N-S to NNW-SSE oriented shortening direction (Santanach, 1994; De Vicente et al., 2011; Martin-González and Heredia, 2011). Contextually, in this western termination, seismic data in the northern retro-wedge indicate limited shortening (Profile P4 of Fig. 2) (i.e. about $35 \mathrm{~km}$ according to AlvarezMarrón et al., 1997). Ambiguous evidence of Iberia subduction exists in the area. In fact, while both gravimetric data (Alvarez-Marrón et al., 1997) and seismic velocity modelling 
(Fernández-Viejo et al., 1998) along the profile P4 would support an almost continuous subhorizontal Iberian Moho. The belt-parallel deep seismic profile ESCIN 3.3 (profile P5 of Fig. 2) shows a repetition of the lower crust-mantle boundary (Ayarza et al., 1998) matching a north-directed subduction of Iberia. In agreement, recompilation of available data in the area led Gallastegui (2000) to conclude that, in the NW corner of the peninsula, the subduction of Iberian lithosphere is still evident. Similarly to profile P5, the profile P6, running parallel to the strike of the Pyrenean orogen, shows a repetition of the lower crust below the Cantabrian Mountains (corresponding to the high $\mathrm{Vp}$ velocity body). This repeated body matches with the indenting lower crust of profile $\mathrm{P}$, and its thickness along the profile P6 displays a strong correspondence with the topographic elevation, indicating that uplift of the Cantabrian Mountains was mostly determined by thickening of the lower crust. All these features indicate that the Cenozoic uplift of the western sector of the Pyrenean orogen related to indentation tectonics (e.g. Gallastegui, 2000; Pedreira et al., 2007), which can be thus extrapolated further to the west of profile P5, that caused coeval north-directed subduction of Iberian lithosphere and scraping of the Iberian crust above a north verging sole-thrust (Quintà and Tavani, 2012).

\subsection{The Cantabrian Transitional Area and surrounding regions}

This is the area where the transition between the Pyrenean and Cantabrian domains occurs. Early studies in the area pointed out the existence of a complex pattern of Cenozoic dip-slip and strike-slip movements (Fig. 3) (e.g. Hernáiz, 1994; Serrano et al., 1994; Espina et al., 1996a). However, until recent years these have been mostly considered as local complications, and the orogenic architecture of the southern Pyrenees has been proposed also in the Cantabrian domain and in the Cantabrian Transitional Area. In particular, a north-dipping low-angle thrust accommodating for about $20 \mathrm{~km}$ of shortening has been inferred to be present below the Cantabrian Mountains (Alonso et al., 1996). Such an interpretation, however, has been recently questioned by Tavani et al. (2011a), who pointed out that microseismicity of the Ventaniella Fault (López-Fernández et al., 2004), which should be displaced at least of $5 \mathrm{~km}$ by this supposed thrust, provides the image of a roughly integer fault zone, down to at least $16 \mathrm{~km}$ of depth. This being incompatible with the existence of an important north-dipping low-angle thrust below the Cantabrian Mountains.

In the study area (Fig. 3a, b), the Cenozoic contractional deformation overprinted inherited Paleozoic and Mesozoic structures, making the Cantabrian Transitional Area an outstanding example of inversion tectonics, with almost all the major fault systems having a pre-orogenic origin (Fig. 3c, d) (García-Mondéjar et al., 1986; Lepvrier and Martínez-García, 1990; Malagón et al., 1994; Pulgar et al.,
1999; Cámara, 1997; Espina et al., 2004; Alonso et al., 2009; Tavani and Muñoz, 2012). In particular, the most important inherited structures are the Ubierna-Ventaniella Fault System and the western portion of the Sierra de Cantabria Fault, which are at least Triassic in age (e.g. Tavani and Muñoz, 2012). These were reactivated during the Late Jurassic to Early Cretaceous rifting associated with the opening of the Bay of Biscay and, together with a system of newly formed NE-SW striking and NW-dipping transversal faults (Tavani and Muñoz, 2012), they formed the southern boundary system of the E-W elongated Mesozoic BasqueCantabrian Basin (Rat, 1988; Malagón et al., 1994; GarcíaMondéjar et al., 1996) (Fig. 3c). During Cenozoic convergence, the Ubierna-Ventaniella Fault System was reactivated as a right-lateral element (Hernáiz, 1994; De Vicente et al., 2011; Tavani et al., 2011a) while, in the study area, the Sierra de Cantabria Fault System acted as a reverse to leftlateral transpressive element (Serrano et al., 1994; Tavani et al., 2011a; Beroiz and Permanyer, 2011; Quintà and Tavani, 2012).

A complex stratigraphic architecture characterises the study area, relating to its complex and polyphasic tectonic history. In a first approximation, two stratigraphic domains can been individuated (Fig. 4): (1) the Basque-Cantabrian Basin, which includes thousands of metres of Mesozoic sediments, and (2) the Asturias-Duero-Ebro domain that, with the exception of the Oviedo Basin, includes only a thin package of Mesozoic sediments (Alonso et al., 1996; Espina et al., 2004). In the Basque-Cantabrian Basin, siliciclastic rocks of the Permo-Triassic Buntsandstein facies unconformably overlie the Paleozoic basement, and were deposited during the first, Early Triassic, rifting. These rocks are overlain by Triassic dolostones and carbonates of the Muschelkalk facies, and by evaporites and clays of the Keuper facies (Lanaja, 1987; García-Mondéjar et al., 1996; Espina, 1997). Upper Triassic to Middle Jurassic rocks include limestones, dolostones, evaporites and marls (e.g. Quesada et al., 1993). Conglomerates, sandstones and clays were deposited during the main Late Jurassic to Early Cretaceous rifting (Lanaja, 1987; Pujalte et al., 1996). Upper Cretaceous limestones and marls unconformably overlie Lower Cretaceous rocks. The Cenozoic sediments mostly include Paleocene to Miocene conglomerates and sandstones (Hernáiz Huerta and Solé Pont, 2000). With the exception of the Asturian Basin, the Duero-Ebro-Asturian domain is characterised by a thinner (even absent) Mesozoic package (Lanaja, 1987; Floquet, 2004), and Cenozoic sediments of this domain frequently directly overlie the Paleozoic basement (Lanaja, 1987).

\section{Orogenic sub-domains}

From a structural point of view, six orogenic sub-domains can be individuated in the area (Fig. 5), whose structural features are described in the following sections, where well 


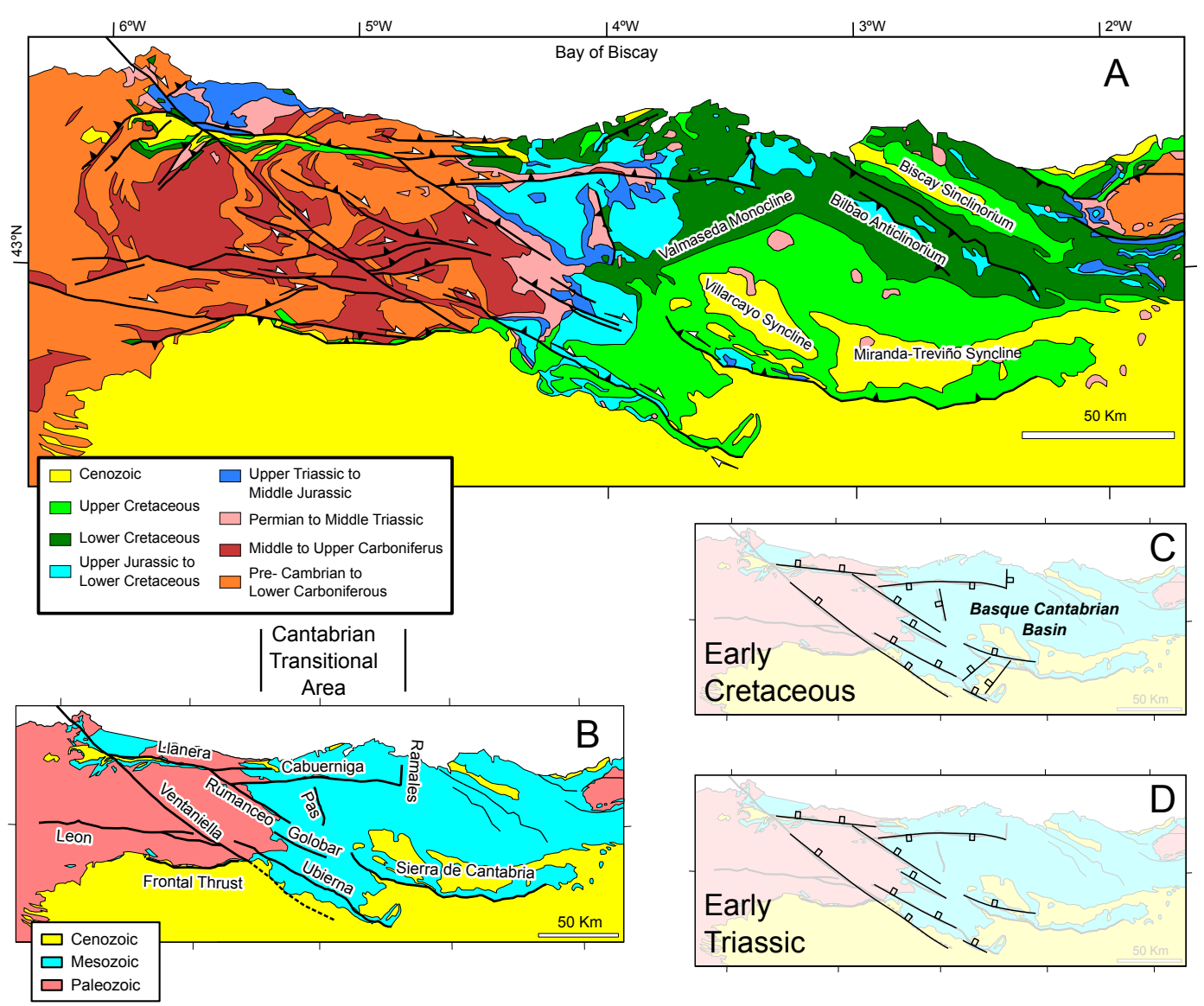

Fig. 3. (A) Geological map of the Cantabrian Transitional Area and surrounding areas (after Tavani et al., 2011a). (B) Labelling of major faults. Reconstruction of fault patterns at the end of Early Cretaceous (C) and Early Triassic (D) (modified from Tavani and Muñoz, 2012 and Quintà and Tavani, 2012).

data, seismic cross sections and macrostructural information will be integrated with both published and newly presented mesostructural data. The aim is to present a large, comprehensive, and trustworthy set of information at different scales of observation, and about the different tectonic stages, which geometrically and kinematically supports the large-scale tectonic interpretation provided in the discussion. There, it is proposed that the central and eastern Cantabrian belt represent a formerly unique thick-skinned belt, where Cenozoic shortening direction was oriented about NNW-SSE. As such, the proto Cantabrian belt flanked to the north a foreland basin, which included the Duero Basin and the Plataforma Burgalesa domain, and differentiated from the thin-skinned Basque Pyrenean belt to the east, which developed due to an about N-S oriented compression. In both belts, the Cenozoic deformation implied the reactivation of Mesozoic extensional faults developed and/or reactivated during NNE-SSW oriented extension associated with the opening of the Bay of Biscay.

\subsection{The foreland basins}

In the study area, the Duero and Ebro foreland basins flank to the south the Pyrenean orogen. Middle Eocene to Miocene syn-orogenic sediments fill both basins (e.g. Alonso et al., 1996; Santisteban et al., 1996; Muñoz-Jimenez and CasasSainz, 1997) and overlie the pre-orogenic substratum, which includes a variable thickness of Triassic to Paleocene sediments (frequently less than few hundreds of metres), and the underlying Paleozoic basement (Lanaja, 1987). Despite of their similar stratigraphic architecture, the two basins display important structural differences (Fig. 6).

The Sierra de Cantabria Thrust Sheet delimits to the north the Ebro Foreland Basin (Sections 1 to 3 of Fig. 6). The detachment level of this thin-skinned element is provided by Triassic evaporites of the Keuper facies. Along this weak level, the thrust sheet overrode the slightly north-dipping layers of the foreland basin, being the amount of displacement in the central portion of this arched thrust at least $20 \mathrm{~km}$ (Riba and Juardo, 1992; Martínez-Torres, 1993; Muñoz-Jimenez and Casas-Sainz, 1997). In this area, the Ebro Basin displays the typical geometry of a foreland basin, with pre-orogenic 


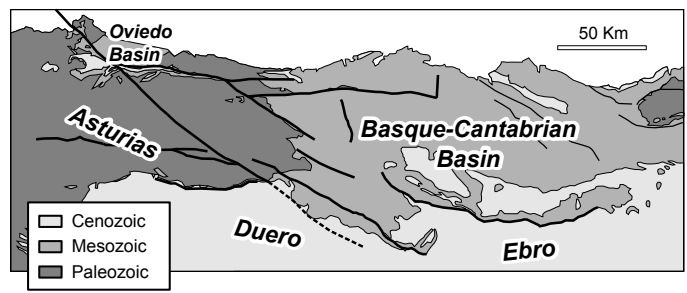

$\begin{array}{cc}\text { Asturias- } & \text { Basque- } \\ \text { Duero-Ebro } & \text { Cantabrian }\end{array}$

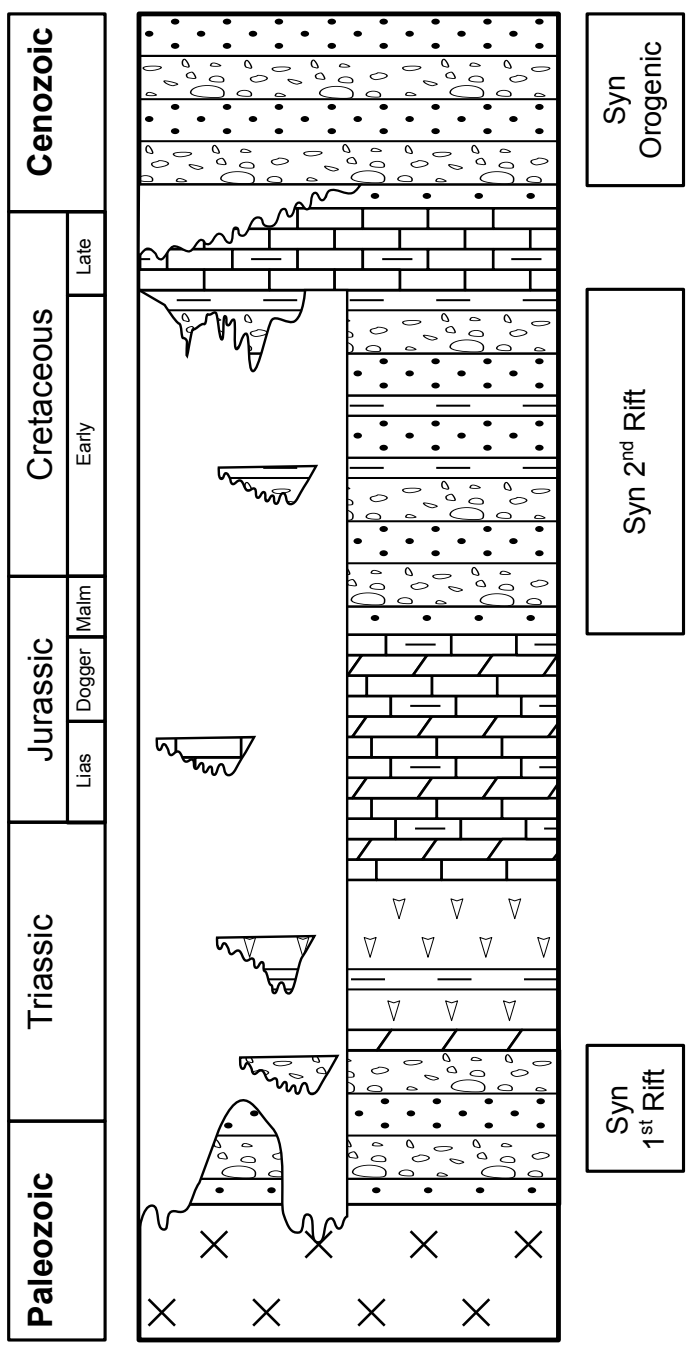

Fig. 4. Synthetic stratigraphy of the area.

layers shallowly dipping toward the north (i.e. toward the belt), and syn-orogenic sediments thickening toward the same direction (their thickness exceeds $5 \mathrm{~km}$ near the Sierra de Cantabria Thrust Sheet). The thickness of Mesozoic sediments abruptly increases across the Sierra de Cantabria Thrust, indicating that this fault largely reworked the southern margin of the Mesozoic Basque Cantabrian Basin.

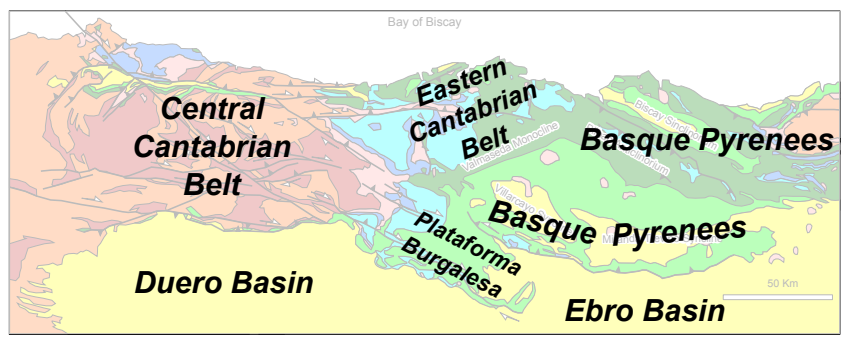

Fig. 5. Cenozoic orogenic sub-domains of the study area.

The Duero Foreland Basin displays a very different geometry (Sections 4 to 8 of Fig. 6). It consists of an E-W trending regional synclinorium extending for about $100 \mathrm{~km}$ from the Ubierna Fault System to the east, to the Galician area to the west. In the northern limb layers are gently southdipping at both tips, while they become near vertical to overturned in the central portion. Roughly E-W striking thrusts and back-thrusts affect this limb (e.g. Gallastegui, 2000), the north-dipping Duero Frontal Thrust being the most important thrust belonging to these reverse fault systems. Paleozoic to Upper Cretaceous rocks in the hanging wall of the Duero Frontal Thrust overrode the Cenozoic materials of the Duero Basin. Cutoff lines of the Duero Front Thrust (Gallastegui, 2000) indicate a very limited displacement (in comparison with the Sierra de Cantabria Thrust), whose average value is less than $4 \mathrm{~km}$ (it locally reaches about $8 \mathrm{~km}$ ). The depocentre of the Duero Basin is located to the south of the Duero Frontal Thrust, where the thickness of syn-orogenic materials is less than $3 \mathrm{~km}$. Toward the west, the substratum of the foredeep rises up and, in the Galician Area, Paleozoic (even Pre-Cambrian) rocks are widespread. However, few exposures of Cenozoic sediments are present there, representing the rest of the Duero Foreland Basin that in Late Eocene to Miocene age included also this area (Martin-González and Heredia, 2011). Onset of foredeep sedimentation in the Duero Basin is dated to Middle to Late Eocene (e.g. Alonso et al., 1996; Santisteban et al., 1996; Martin-González and Heredia, 2011), when deposits were supplied from an uplifted area located to the north of the Oviedo Basin, approximately in correspondence of the present-day shoreline. Consistently, Late Eocene to Oligocene strata onlap to the south (Sections 4 to 8 of Fig. 6), even in the northern limb of the basin (Herrero et al., 2004).

\subsection{The Plataforma Burgalesa domain}

The Plataforma Burgalesa domain interrupts the structural continuity between the Ebro and Duero basins. At a regional scale, this domain is an ESE-dipping monocline bounded to the south by the right-lateral Ubierna Fault System (Tavani et al., 2011a) and to the north by the western termination of the arc-shaped Sierra de Cantabria Thrust (Fig. 7). The Ubierna Fault System includes the Ubierna Fault and the southeastern 

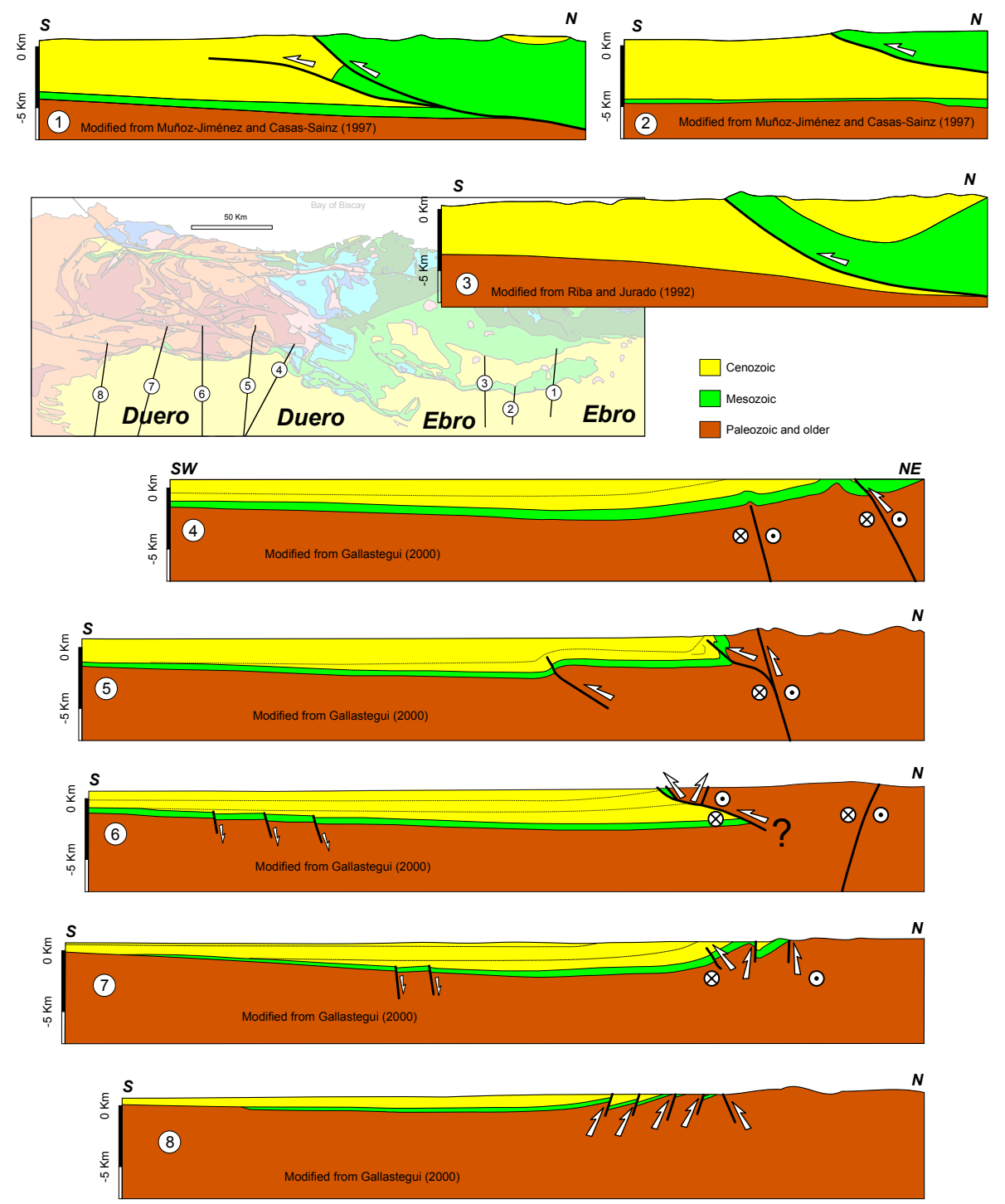

Fig. 6. Geological cross sections across the mountain front of the study area.

termination of the Ventaniella Fault (Fig. 7). As previously mentioned, these elements formed the southwestern boundary of the E-W elongated Upper Jurassic to Lower Cretaceous Basque-Cantabrian Basin. The Mesozoic extensional architecture of this fault system is well-imaged in seismic sections striking at a high angle to the Ubierna Fault, where extensional growth geometries are recognisable (Fig. 8). In the hanging wall of the Ubierna Fault, the thickness of Upper Jurassic to Lower Cretaceous syn-rift sediments increases toward NNE, passing from less than $1 \mathrm{~s}$ (TWT) close to the fault, to about $2 \mathrm{~s}$ away from it. In the vicinity of the fault, almost flat-lying reflectors of the syn-rift sequence are characterised by onlap relationships to the underlying Upper Triassic to Middle Jurassic pre-rift units, which dip toward NNE and attain a subhorizontal attitude only away from the fault. Below these NNE-dipping pre-rift reflectors, the transpar- ent seismic facies belongs to the Triassic evaporites. Further below, subhorizontal reflectors of the Permo-Triassic Buntsandstein facies are imaged. As pointed out by Tavani et al. (2011a), these geometries are diagnostic of an extensional forced folding mechanism (e.g. Brown, 1980; Laubscher, 1982), where the Triassic evaporites ensured the decoupling between faulted Paleozoic rocks and folded Mesozoic cover sequence. The thickness of the entire Mesozoic sedimentary package reduces to few hundreds of metres in the area between the Ventaniella and Ubierna faults. Along the central portion of the Ubierna Fault, rocks of similar age are exposed in the hanging wall and in the footwall, as recognisable despite the presence of several second-order folds and faults in the southern block of the Ubierna Fault. This, together with the well-preserved Mesozoic extensional architecture and with macro- and meso-structural data (Tavani 

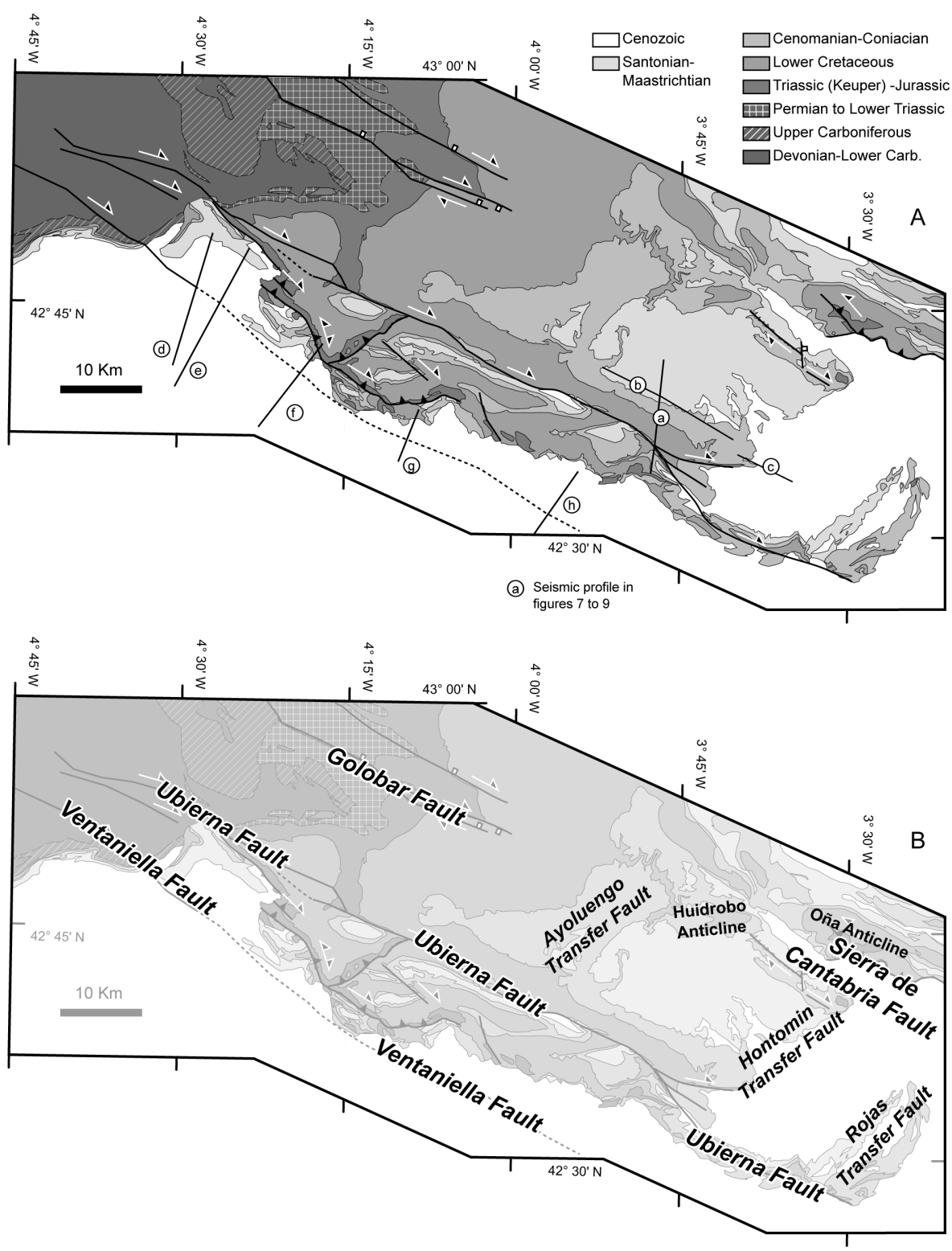

Fig. 7. (A) Geological map of the Plataforma Burgalesa domain (modified from Tavani et al., 2011a), with traces of seismic lines. (B) Labelling of major faults.

et al., 2011a), highlights an almost exclusive strike-slip behaviour during the Cenozoic inversion stage, with a very subordinated reverse component. Consistently with WNW-ESE directed right-lateral wrench tectonics, evidence of dip-slip inversion is found along the three main transversal elements striking at a high angle to the Ubierna Fault: the Ayoluengo, Rojas and Hontomín transversal elements. This is particularly evident across the Hontomín Transversal Fault (Fig. 9), where the thickness of the syn-rift sedimentary package reduces toward SE, indicating the presence of deeply rooted NW dipping Mesozoic extensional faults. The same fault has been positively inverted during Cenozoic, as witnessed by the uplift of its hanging wall and by the presence of Cenozoic contractive growth strata. Similarly, the Rojas System, being the contractional horsetail termination of the Ubierna Fault System (Fig. 7), displays all the attributes of an inverted extensional transversal fault. In fact, well data indicate the presence of many hundreds of syn-rift sediments immediately to the west of this element, while to the east Cenozoic sediments in many cases directly overlie the Paleozoic basement (Lanaja, 1987). The inversion of the three above-mentioned NW-dipping extensional transversal faults is also testified by the staircase geometry of the Plataforma Burgalesa domain, which along a WNW-ESE direction is divided by these elements in three sectors, where exposed rocks are (from the 


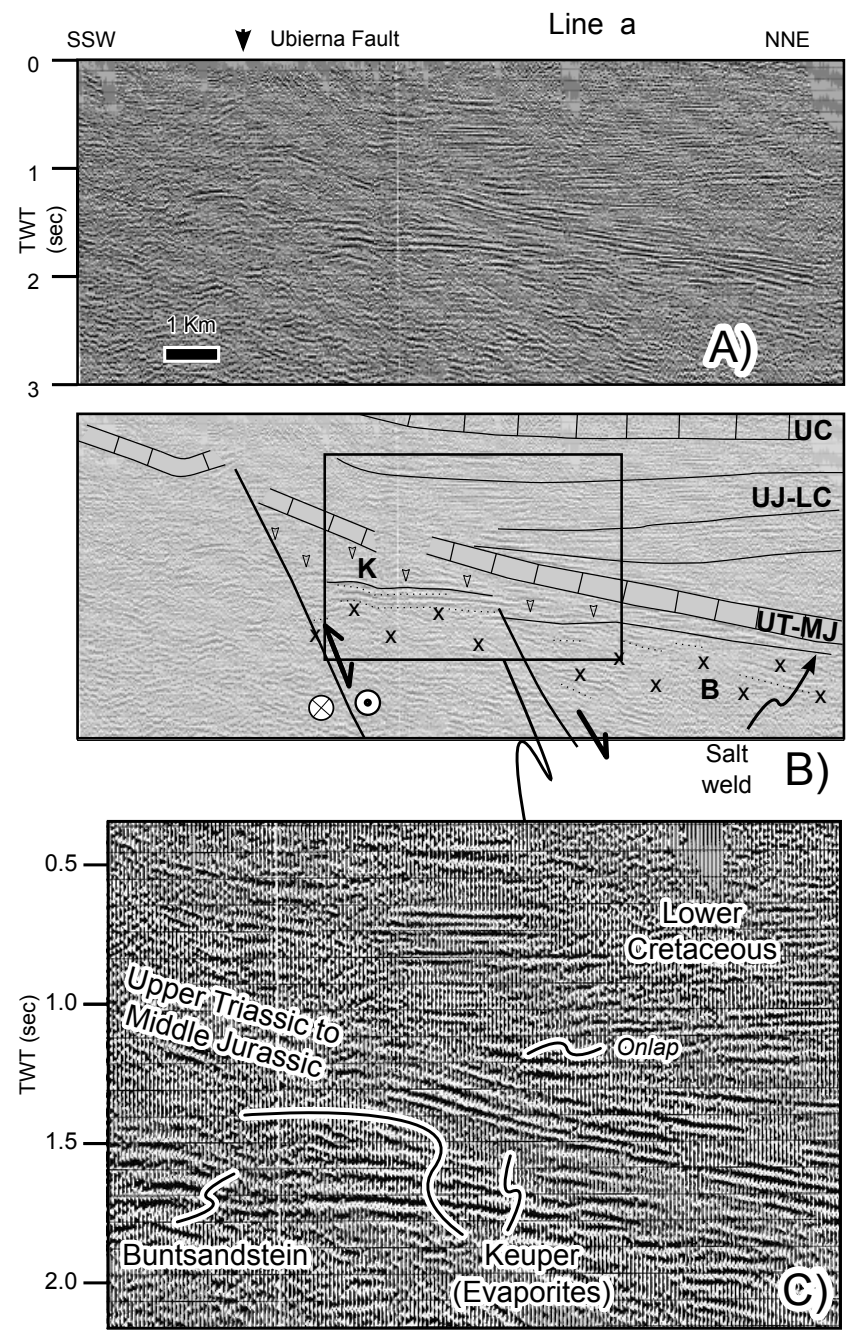

Fig. 8. (A) N-S striking seismic line a, with line-drawing (B) and detail illustrating the relationships between cover, evaporites and basement (C). Hereafter C is Cenozoic; UC is Upper Cretaceous; UJ-LC is syn-rift Upper Jurassic to Lower Cretaceous; UT-MJ is pre-rift Upper Triassic to Middle Jurassic; $\mathrm{K}$ is Keuper evaporites; $\mathrm{B}$ is basement.

east to the west) Cenozoic, Upper Cretaceous, and Jurassic to Cretaceous in age (Fig. 7b).

The thickness of Mesozoic sediments, which strongly reduces to the SW of the Ubierna Fault, further reduces to the south of the Ventaniella Fault. Seismic sections, located to the SW of the western termination of the Ubierna Fault, show that the south-dipping northern limb of the Duero Basin continues in this area. It is in fact well-recognisable, despite the slight deformation produced by the Ventaniella Fault (Fig. 10), that this area has a negligible, and frequently opposite, apparent vertical displacement. Toward SE the reverse component of the Ventaniella Fault slightly increases, and, contextually, opposite vergences are often observed (Fig. 10).

\subsection{The Basque Pyrenees}

The southern leading structure of the Basque Pyrenees is the Sierra de Cantabria Thrust Sheet (Fig. 11). Anticlines and synclines in the hanging wall of the Sierra de Cantabria Thrust have wavelengths ranging from 1 to $20 \mathrm{~km}$, and the Triassic evaporites provide the deeper décollement level (Martínez-Torres, 1993). Both depth of detachment and folds wavelength increase to the north, in correspondence with the WNW-ESE striking Bilbao anticlinorium (Fig. 3), which forms part of the transitional area between the south- and north-verging Basque Pyrenees (Gómez et al., 2002; Pedreira et al., 2007; Ábalos et al., 2008). The Sierra de Cantabria Thrust Sheet has a northward concave shape, and both the frontal anticline and the trailing synclinal system strike about E-W in the central portion of the thrust sheet, while they progressively attain a NW-SE and WSE-ENE orientation to the west and to the east, respectively. In detail, the thrust sheet is divided into two sectors flanking to the north the Ebro Basin and the Plataforma Burgalesa domain, respectively. All available data, including a deep well (Well Corrès-1 in Fig. 11), indicate that the eastern portion of the Sierra de Cantabria Thrust Sheet is a large-displacement thin-skinned ramp-related anticline (Fig. 6, sections 1 to 3). Things become more complex to the west of the Pancorbo Transversal System, which is an anticline including a northern NW-SE striking segment and a southern segment striking about $\mathrm{N}$ $\mathrm{S}$. To the west of this transversal anticline, the hanging wall of the Sierra de Cantabria Thrust includes several secondorder folds paralleling the trend of the thrust sheet (which further to the west attains a NW-SE strike) and also a more external and open anticline, namely the Villalta anticline of the Plataforma Burgalesa domain. The wavelength of the main anticline (i.e. the Oña anticline) increases with respect to the eastern sectors, and available deep wells indicate the absence of Cenozoic materials below both the western portion of Sierra de Cantabria Thrust Sheet (Navajo-1 Well) and the Plataforma Burgalesa domain (Rojas NE 1 Well) (Lanaja, 1987). Another important difference between the western and eastern sectors of the Sierra de Cantabria Thrust Sheet concerns the amount of "admissible" displacements along the frontal thrust. As previously mentioned, to the east of the Pancorbo System the south-directed displacement exceeds 20 km (Riba and Juardo, 1992; Martínez-Torres, 1993; Muñoz-Jimenez and Casas-Sainz, 1997). Conversely, to the north of the Plataforma Burgalesa domain, the displacement associated with the Sierra de Cantabria Thrust is reduced to less than few $\mathrm{km}$. This is testified by the following evidence: (1) the thrust fault progressively disappears westward of the Oña anticline; (2) the Navajo-1 well did not encounter any important repetition of the multilayer, and found $\mathrm{Pa}$ leozoic rocks below a thick package of Triassic evaporites (Lanaja, 1987); (3) the trace of the E-W striking Huidobro anticline, which is located immediately to the south-west of the Sierra de Cantabria Thrust, is recognisable in the western 

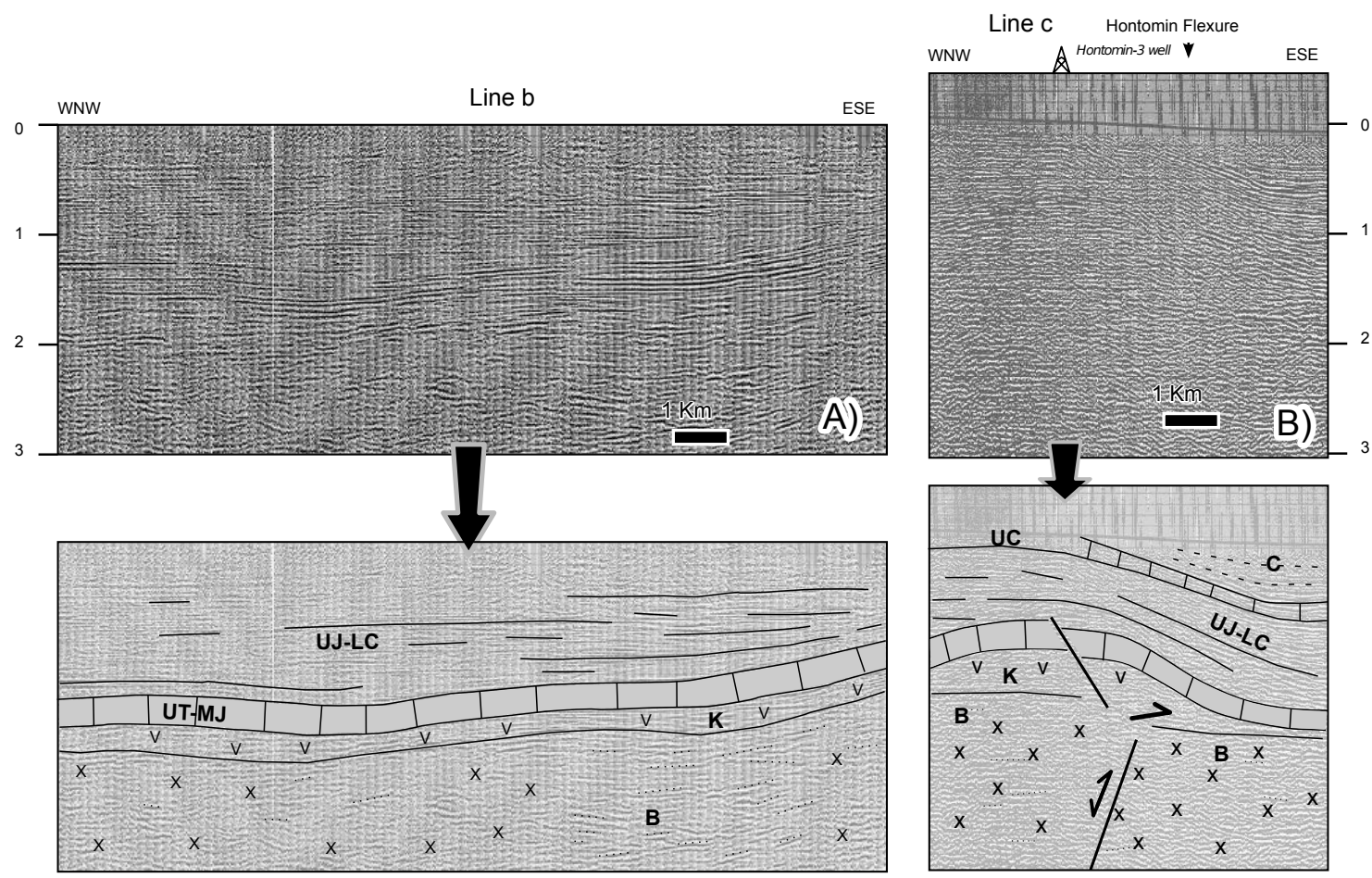

Fig. 9. WNW-ESE striking seismic lines b (A) and c (B), with corresponding line-drawing.

termination of the Oña anticline (see figure 3 in Quintà and Tavani, 2012), geometrically imposing a limited amount of displacement (i.e. about a couple of $\mathrm{km}$ ). This sets problems for the interpretation of the Sierra de Cantabria Thrust as resulting from the inversion of a single extensional fault, as it would imply a drastic and sharp lateral decreasing of southdirected displacement. A consistent solution for this problem will be presented in the discussion.

The development of roughly E-W striking anticlines and synclines is one of the later stages of the Cenozoic deformational sequence recorded in the area. Comparison between mesostructures hosted in Upper Cretaceous rocks of the Plataforma Burgalesa domain and of the southern limb of the Villarcayo syncline (Quintà and Tavani, 2012) has revealed a common complex history that is summarised in Fig. 12. According to data presented in Quintà and Tavani (2012), in both areas, the oldest deformational pattern, which affects all the Upper Cretaceous sequence, is represented by Cenozoic extensional structures developed during thermal subsidence of the Basque-Cantabrian Basin (Fig. 12a). This event was postdated by two early-orogenic extensional stages, associated with outer-arc extension in the peripheral bulge and along-foredeep stretching, respectively (Fig. 12b). In both areas, and for both events, mesostructural data indicate a WSW-ENE elongated foredeep, thus forming an angle of about $20^{\circ}$ with the present-day trend of both Duero and Ebro foredeeps. These stages were in turn followed by a NNW-SSE oriented layer-parallel shortening event (Fig. 12c), which caused the right-lateral reactivation of inherited WNW-ESE striking structures, and the development of WSW-ENE striking folds, being the Huidobro anticline of the Plataforma Burgalesa domain the major one. Reverse reactivation of WNW-ESE striking faults forming part of the Sierra de Cantabria Thrust Sheet occurred during a later stage, characterised by an about N-S oriented compression. The two domains to the north and to the south of the Sierra de Cantabria Fault differentiated in a later deformation stage. To the north of the Sierra de Cantabria Thrust, an E-W to WSW-ENE oriented compression occurred during this final deformation stage (Fig. 12d), causing left-lateral reactivation of WNW-ESE striking elements, including the western termination of the Sierra de Cantabria Fault, and development of $\mathrm{N}-\mathrm{S}$ striking compressive structures.

\subsection{The eastern Cantabrian belt}

The transition between the Basque Pyrenees and the eastern Cantabrian belt occurs across the Cenozoic Valmaseda monocline, which is a $60 \mathrm{~km}$-long WSW-ENE striking and SSE-dipping monocline (Figs. 3 and 11). To the NW of this monocline, in the eastern Cantabrian belt, exposed rocks mostly range in age from Triassic to Early Cretaceous. The macro- and mesostructural Mesozoic extensional architecture is outstandingly preserved in the northern portion of the area, while Cenozoic deformation appears to be less developed. 

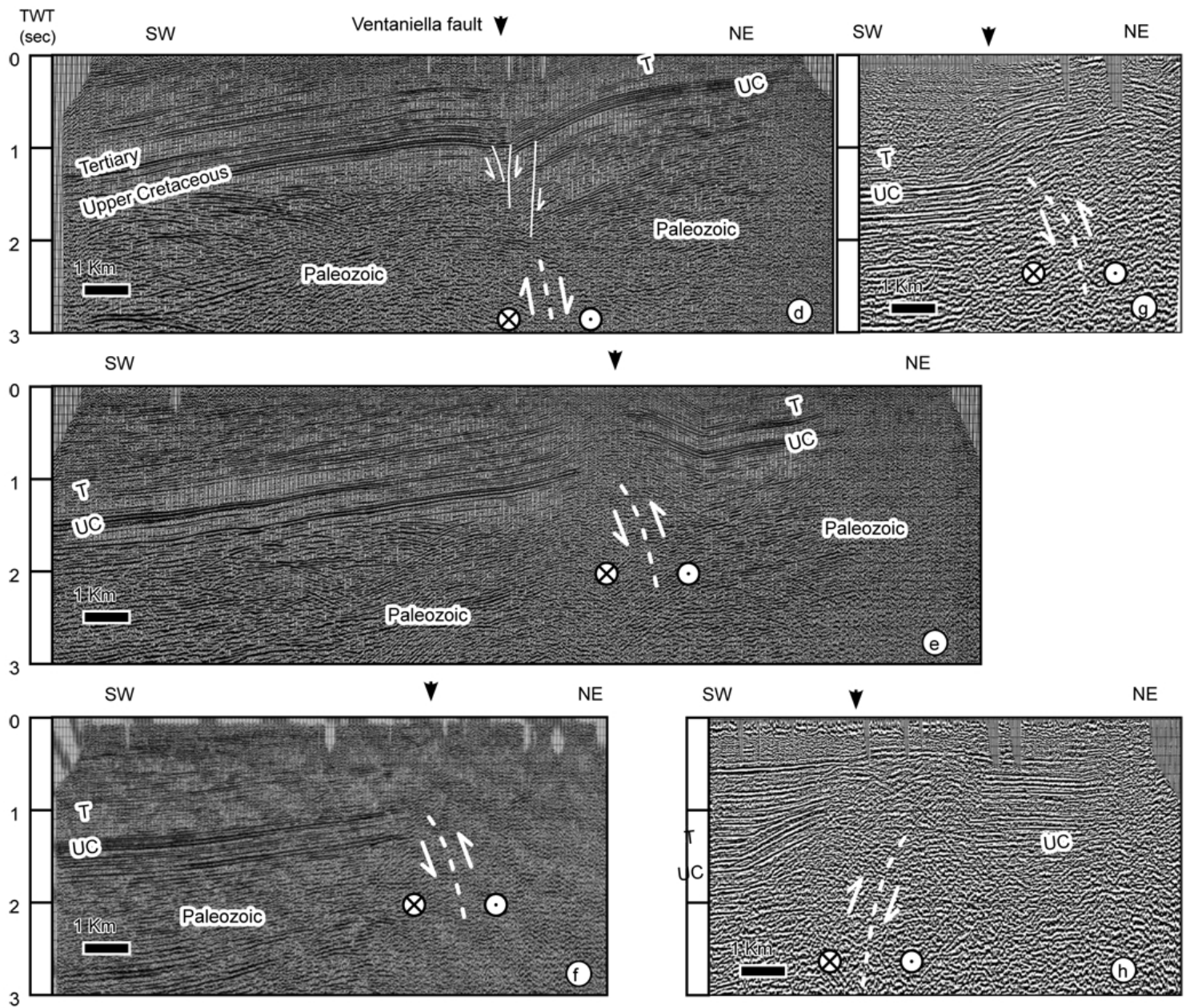

Fig. 10. Seismic lines crossing the Ventaniella Fault in the Duero Basin.

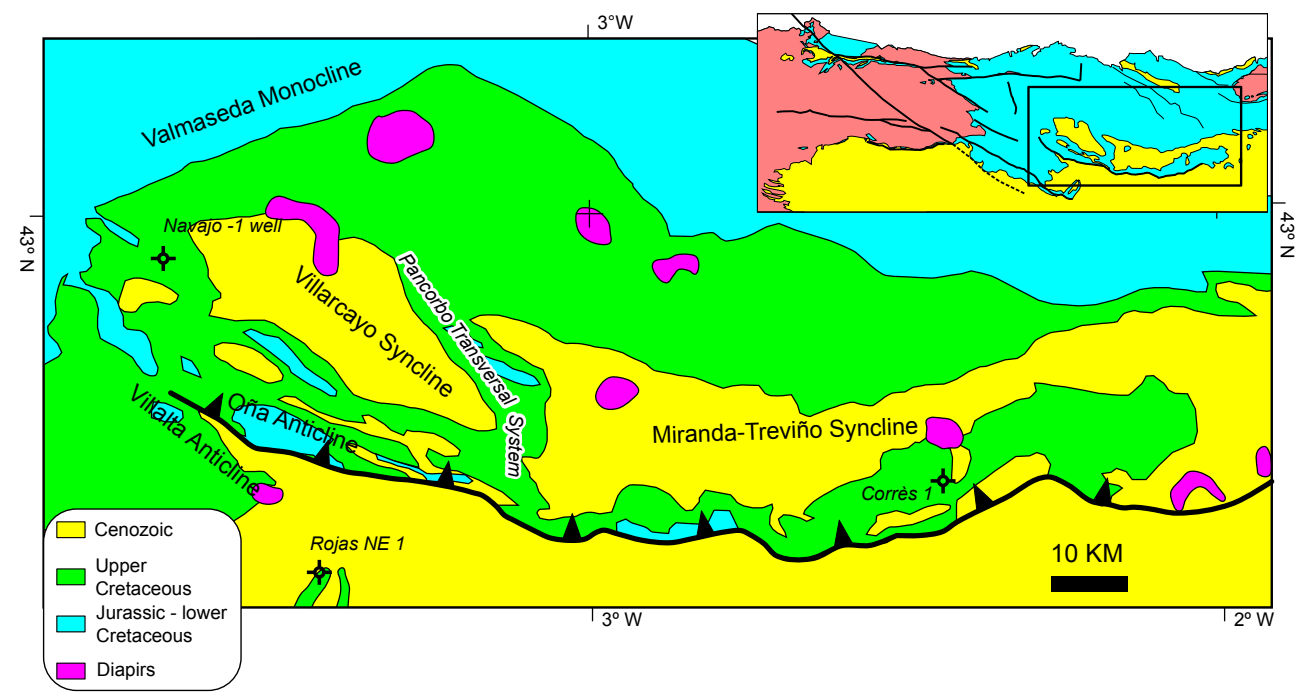

Fig. 11. Geological map of the southern portion of the Basque Pyrenees. 

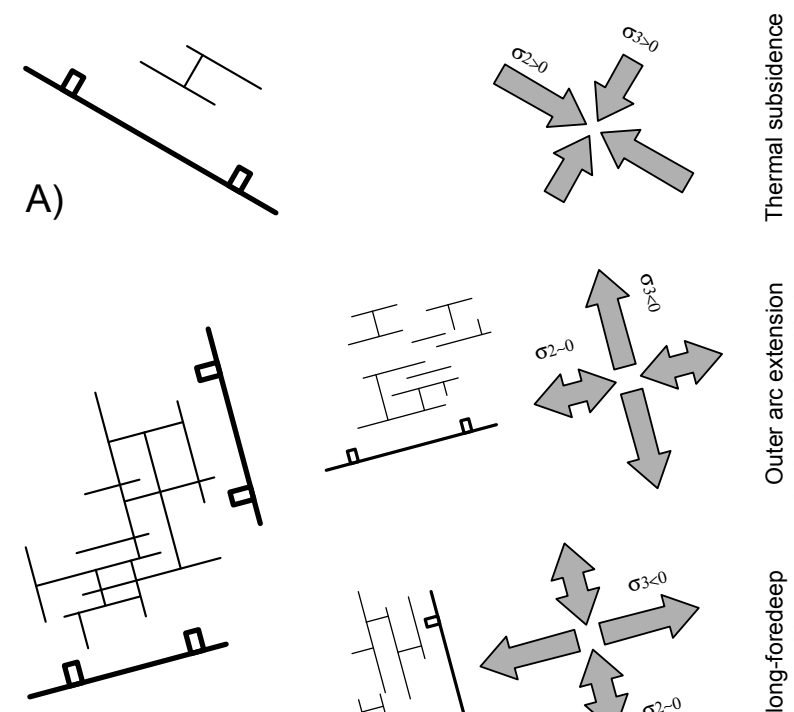

B)
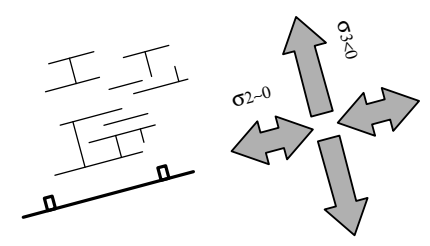

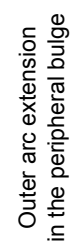

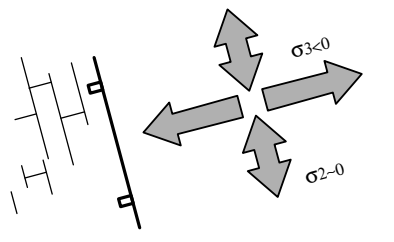

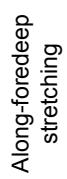

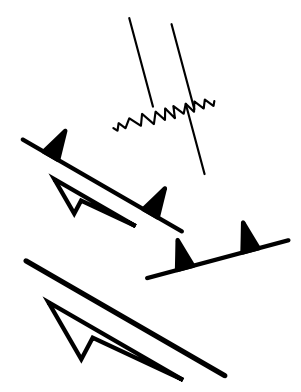

C)
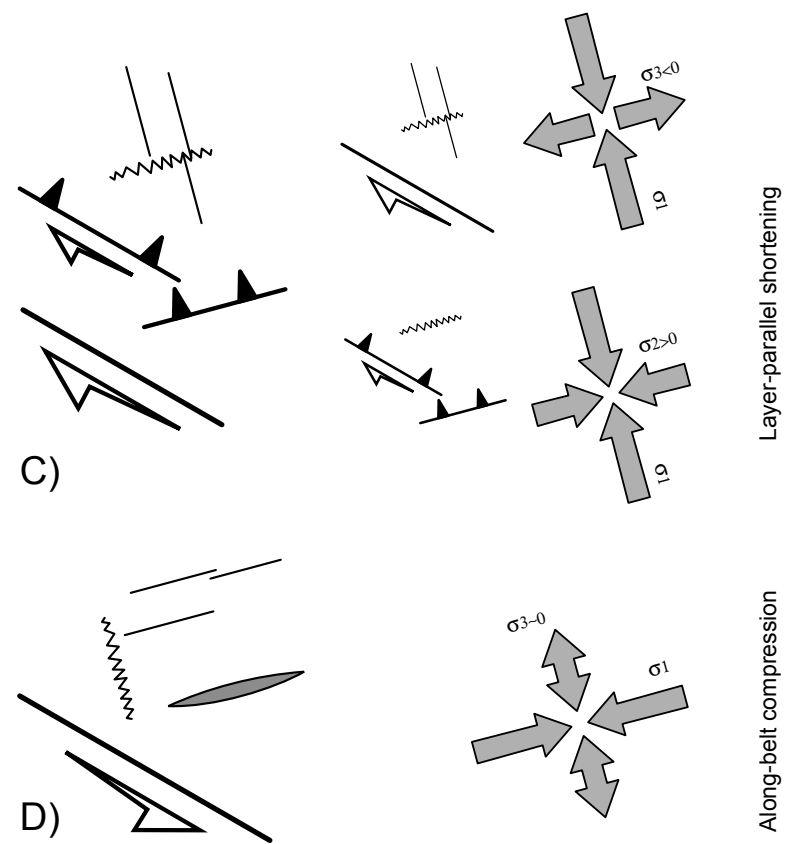

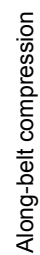

Fig. 12. Fracture patterns, stress fields and associated tectonic events recognised in the Upper Cretaceous limestones of the Plataforma Burgalesa domain and of the Villarcayo syncline, after Quintà and Tavani (2012). See text for details.

In the northern part of this sub-domain, the major feature is the E-W striking and south-dipping Cabuérniga Fault (Figs. 3 and 13a). This is probably a Paleozoic fault, reactivated as an extensional element during both Triassic and Upper Jurassic to Lower Cretaceous rifting events (Garcia-Mondejar et al., 1986), and later inverted during Pyrenean orogeny. The Pas and Ramales anticlines strike about N-S, and represent inherited Upper Jurassic to Lower Cretaceous transversal el- ements (Tavani and Muñoz, 2012), which have been positively inverted during the Cenozoic. Data reported in Tavani and Muñoz (2012) indicate that mesostructures hosted in Upper Triassic to Lower Cretaceous sediments exposed along the Cabuérniga Fault System are mostly arranged in a rather simple extensional pattern. This pattern includes joints and extensional faults striking about $10^{\circ} \mathrm{N}$ and $100^{\circ} \mathrm{N}$ and a subordinated NNW-SSE-striking extensional fault set (Fig. 13b). The same authors have reported that, in the eastern portion of the Cabuérniga Fault, this extensional assemblage is postdated by NW-SE-striking veins frequently describing an echelon pattern, consistent with a Cenozoic E$\mathrm{W}$ oriented right-lateral movement (Fig. 13c). In this work are reported similar strike-slip related features, which have been found along the central and western segments of the fault, further documenting the right-lateral transpressive reactivation of the Cabuérniga Fault. In particular, in its central portion, the Cabuérniga Fault has Devonian rocks and Jurassic marls in the northern and southern block, respectively. Locally, the contact is provided by a steeply northdipping plane (Fig. 13d), with associated right-lateral transpressive to purely strike-slip slickenlines (Fig. 13e). Consistently with this, the damage zone of the northern block (i.e. the Devonian block) hosts abundant right-lateral mesofaults, including both synthetic faults striking WNW-ESE and E-W striking faults paralleling the master fault (Fig. 13f). Further to the west, south-dipping Upper Triassic to Lower Jurassic limestones in the southern block of the Cabuérniga Fault host tilted reverse (Fig. 14a) and right-lateral (Fig. 14b) assemblages, the latter postdating an early extensional assemblage including two perpendicular joint sets oriented at high angle to bedding and striking, after unfolding, NNE-SSW and WNW-ESE, respectively (Fig. 14b), i.e. parallel and perpendicular to the Mesozoic extension direction inferred by Tavani and Muñoz (2012). E-W to WNW-ESE striking right-lateral faults, together with NNW-SSE oriented movements observed along tilted reverse faults, are consistent with a right-lateral transpressive kinematics of the E-W striking Cabuérniga Fault System, which overprinted the Mesozoic extensional stage. Although the above-described elements testify for a strike-slip reactivation of the Cabuérniga Fault, it must be remarked once again that the mesostructural pattern observed in the rocks surrounding this element mostly developed during the Mesozoic extensional stages.

Immediately to the south of the eastern termination of Cabuérniga Fault, the WSW-ENE striking Selaya Fault System developed in Late Jurassic to Early Cretaceous times (Fig. 15a). Mesostructural data collected in Jurassic and Lower Cretaceous pre- to syn-rift sediments exposed along the northeastern termination of the Selaya Fault System are presented below. Mesostructures observed in the area include only joints and extensional faults. The former strike NE-SW, NW-SE and NNE-SSW (Fig. 15b). The first two sets are mutually orthogonal, and frequently occur together (Fig. 15c), describing either ladder (with the NE-SW set 

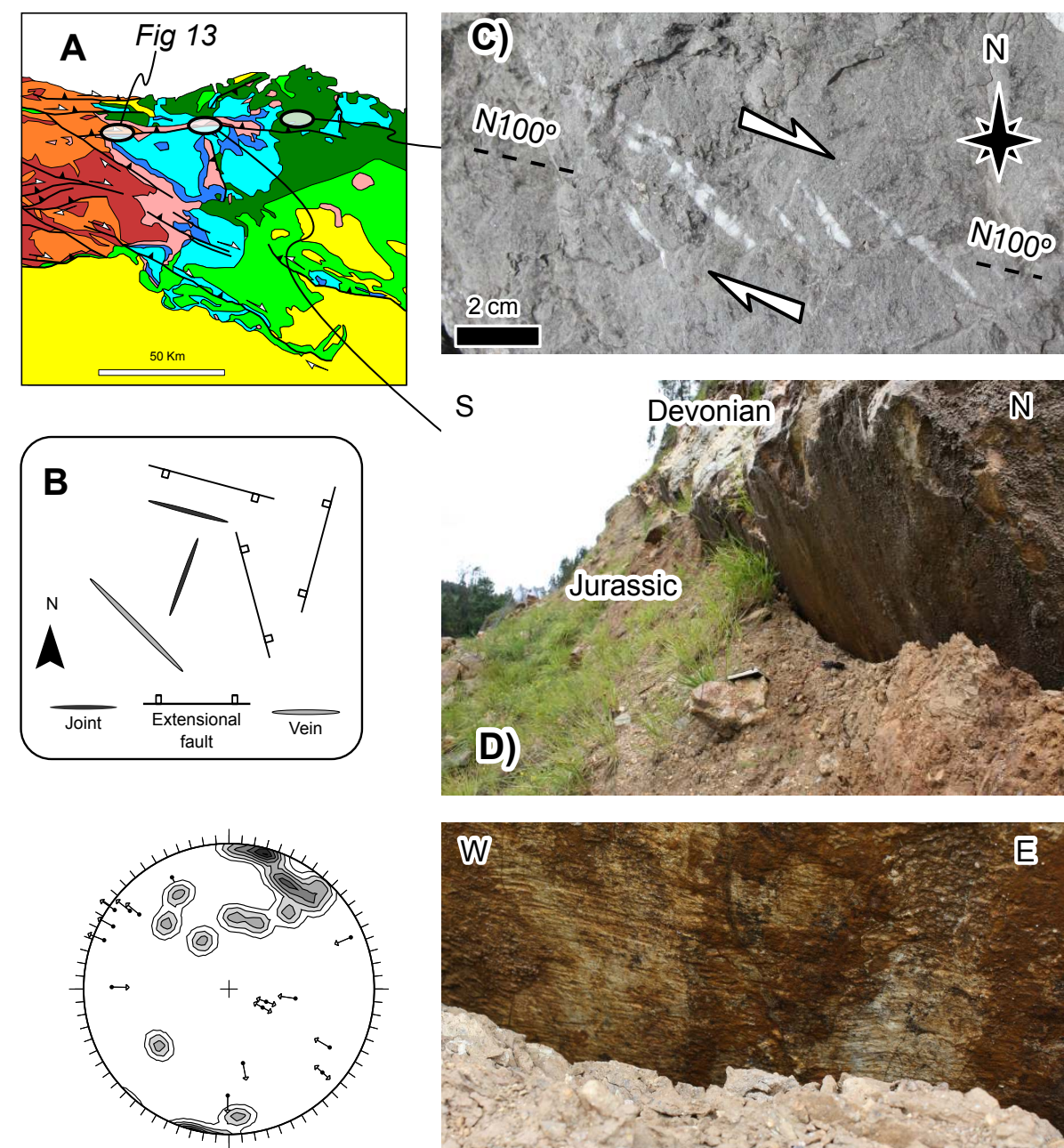

Data Number $=15$ Contouring interval $=3 \%$ $\mathbf{F}$

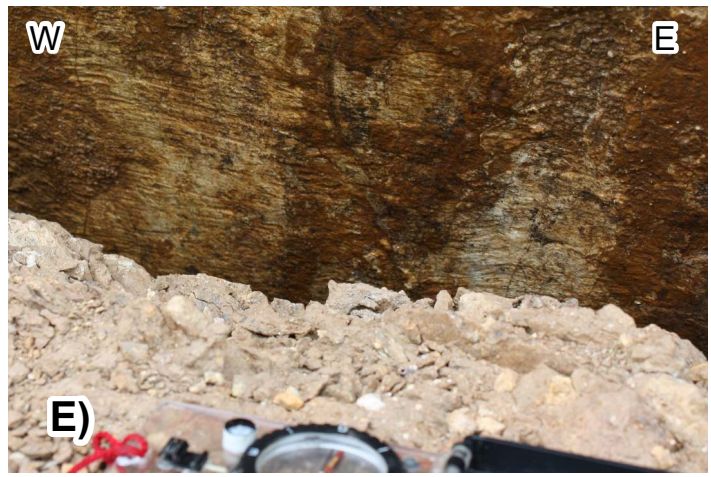

Fig. 13. (A) Geological map of the Cabuérniga Fault area. (B) Schematic map view of mesostructural patterns recognised in the area by Tavani and Muñoz (2012). (C) Details of NW-SE striking en echelon veins, consistent with an E-W oriented right-lateral motion. (D) Photo of the tectonic contact between Devonian rocks and Jurassic marls along the central portion of the Cabuérniga Fault, with detail of right-lateral slickenlines $(\mathbf{E})$ and stereoplot of mesofaults in the northern damage zone of the fault $(\mathbf{F})$.

being the systematic joint set) or grid patterns (e.g. Gross, 1993; Rives et al., 1994). Faults are characterised by the same directions as joints. Few slickenlines have been observed, showing an important left-lateral transtensive component along NE-SW striking faults, which provides a stretching direction oriented perpendicular to the NNE-SSW striking joints and faults. Overprinting relationships, and the presence of NE-SW and NW-SE striking joints, indicate that NESW striking faults developed within an extensional framework and were later reactivated with a left-lateral transtensional kinematics (Fig. 15d) during a WNW-ESE oriented stretching. It is worth remarking that this second stretching direction is oriented about perpendicular to the regional stretching direction associated with the Late Jurassic to Early Cretaceous rifting (Tavani and Muñoz, 2012).
To the SW, the Rumaceo and Golobar faults affect Paleozoic and Mesozoic rocks. This area represents the transition between the Plataforma Burgalesa domain and the Cantabrian belt. Progressively older rocks are exposed to the west (Fig. 16), which allows for the map view of crosssectional geometries representing the deeper portion of the Plataforma Burgalesa domain. As previously mentioned, the WNW-ESE striking Rumaceo and Golobar faults are Triassic in age (even older); they have been reactivated during the Late Jurassic to Early Cretaceous rifting (Espina et al., 2004; Tavani and Muñoz, 2012) and, later, during the Cenozoic inversion stage (Espina et al., 2004; Tavani et al., 2011a). Mesozoic rocks are exposed to the east, overlying Triassic evaporites of the Keuper facies. Below these, the Muschelkalk and the Buntsandstein facies are on top of Paleozoic 

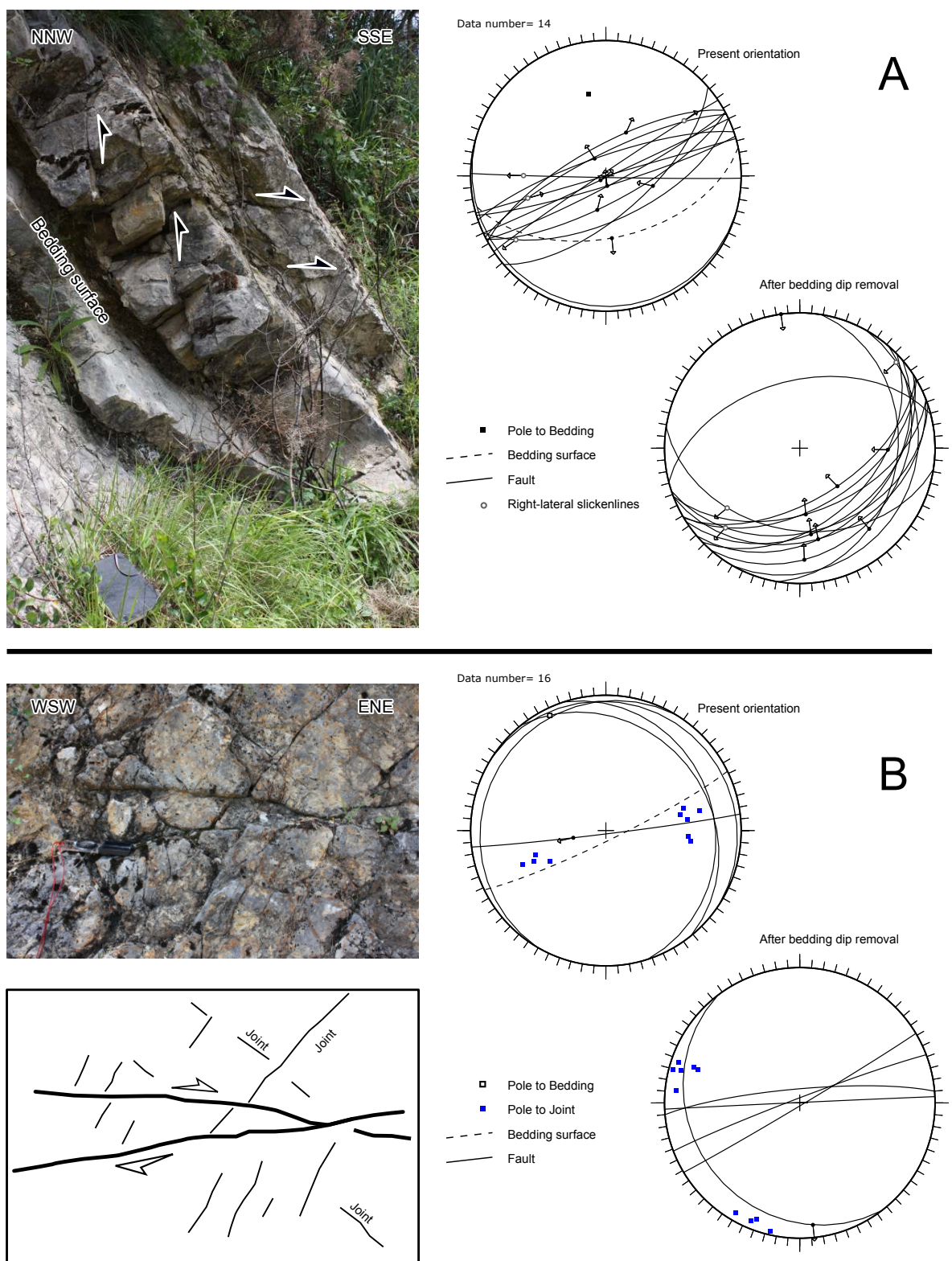

Fig. 14. Mesostructures and corresponding stereoplots of two outcrops in the southern block of the Cabuérniga Fault near its western termination. (A) Tilted reverse faults. (B) Tilted right-lateral fault system postdating an earlier extensional system formed by two sets of mutually perpendicular joints.

rocks, which are exposed to the west. A strong decoupling exists between Paleozoic rocks and the post-evaporite portion of the multilayer, with evaporite migration testified by salt weld and salt accumulation in synclinal areas. Faults mostly affect the basement, while the Upper Triassic to Middle Jurassic sequence is only poorly faulted, and drapes the evaporite layer. Cenozoic inversion of the major basement faults has occurred within a right-lateral transpressive framework (Tavani et al., 2011a), and led to the development of anticlines and synclines formed due to the buttressing effect of the extensional faults coring these anticlines. Many faults penetrate into the Mesozoic cover sequence, but with relatively limited displacements (i.e. less than few hundreds of metres). The fact that faults preserve their integrity across the evaporites indicates that, in this area, these did not act as a regionally important décollement level. As reported in Tavani and Muñoz (2012), in this area the Upper Jurassic to Lower Cretaceous extensional stage was characterised by the same stretching direction as found in the Cabuérniga Fault area, i.e. about $15 / 20^{\circ} \mathrm{N}$, which led to the slightly oblique reactivation of both Rumaceo and Golobar faults. Extensional mesostructures developed during this stage include joints and 

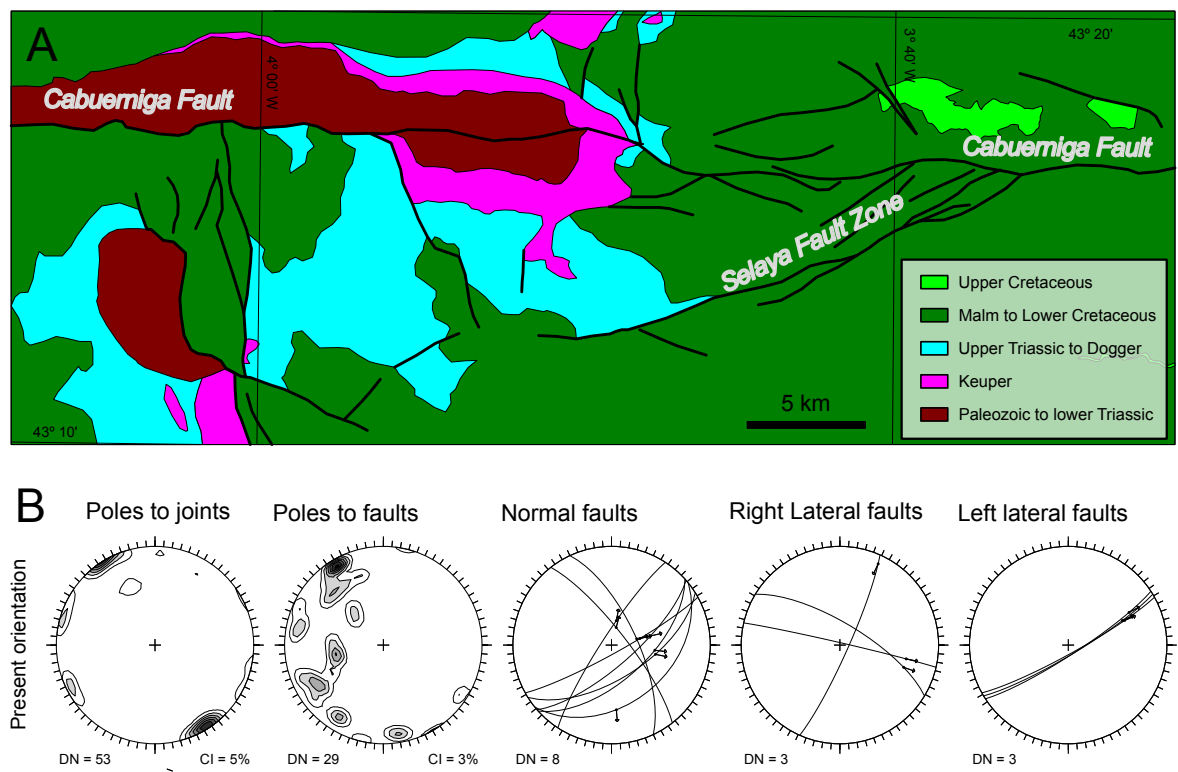

$\mathrm{DN}=3$
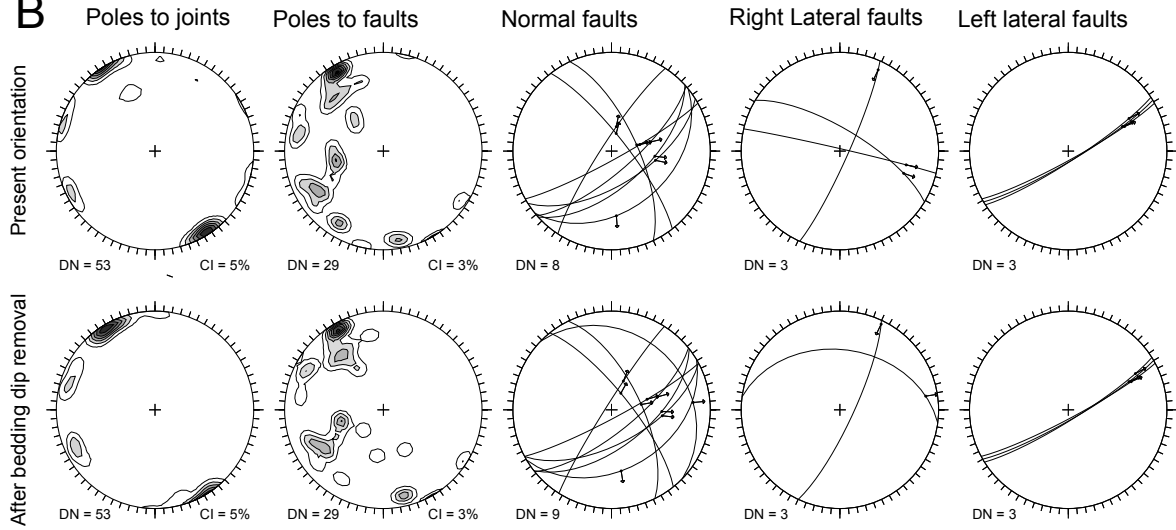

$\mathrm{DN}=3$
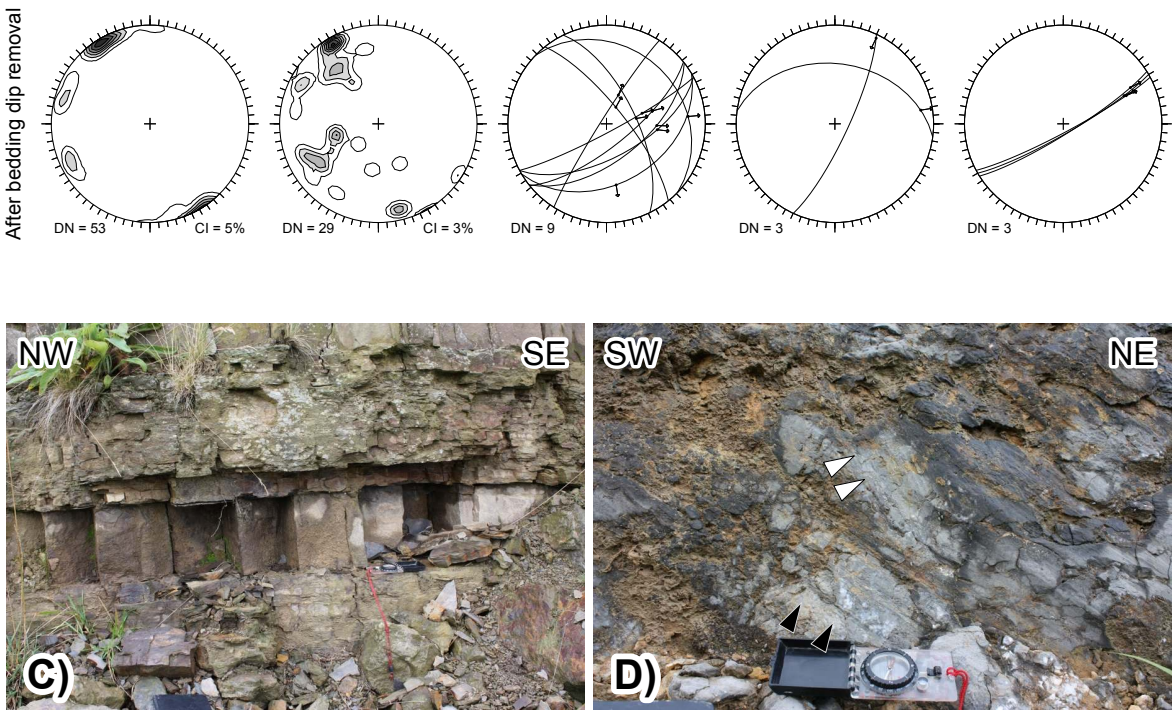

Fig. 15. (A) Geological map of the Selaya Fault System. (B) Mesostructural data collected along the northeastern termination of the fault system. (C) Bedding-perpendicular orthogonal joint sets. (D) Detail of a SW-NE striking almost dip-slip extensional fault (white arrows) later reactivated as a left-lateral transtensive element (black arrows).

extensional faults, which are clustered in several sets, the three most important being oriented parallel and perpendicular to the stretching direction, and about NE-SW (Tavani and Muñoz, 2012). WSW-ENE striking pressure solution cleavages and NNE-SSW striking joints and veins pervasively affect Jurassic limestones in the northern block of the Rumaceo Fault, and have been related to the right lateral reactivation of this fault (Tavani et al., 2011a).

\subsection{The central Cantabrian belt}

In the central portion of the Cantabrian Mountain Range, Paleozoic rocks deformed during the Hercynian orogeny are widespread. These are represented by Middle to Late Carboniferous syn to post-orogenic deposits, unconformably overlying pre-Cambrian to Lower Carboniferous rocks (Julivert, 1971; Pérez-Estaún et al., 1991; Dallmeyer et al., 1997). Hercynian and Late Hercynian faults are wellpreserved, and were reactivated during both Mesozoic rifting and Cenozoic convergence stages (e.g. Pérez-Estaún et al., 1988; Lepvrier and Martínez-García, 1990; Pulgar et al., 1999; Alonso et al., 1996; Gutiérrez-Alonso et al., 2008). With the exception of the Cenozoic Duero Frontal Thrust, the major structures of the area, including the Ventaniella and Leon faults, have a Paleozoic age (Lepvrier and MartínezGarcía, 1990; Alonso et al., 2009). The NW-SE striking 


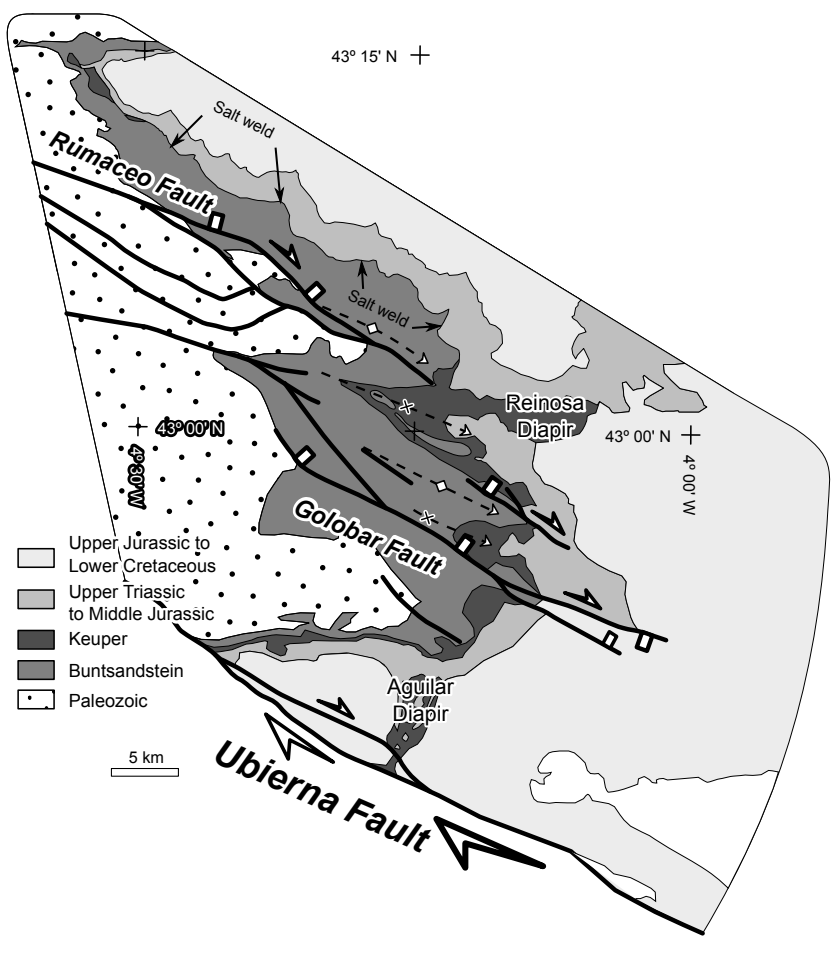

Fig. 16. Geological map of the Golobar and Rumaceo faults area.

Ventaniella Fault crosses the entire Cantabrian Mountain Range, and its trace is exposed for more that $150 \mathrm{~km}$. It continues to the NW, in the Bay of Biscay, and to the SE, in the Duero Foreland Basin (as seen in seismic lines of Fig. 10), reaching a length of at least $250 \mathrm{~km}$. Hercynian markers in the central portion of the fault are displaced of about $4 \mathrm{~km}$ in a right-lateral sense (García-Ramos et al., 1982; Heredia et al., 1990; Alvarez-Marrón, 1995). The Cenozoic age of rightlateral movements along this fault is well-constrained, and it is indicated by displaced Cenozoic sediments of the Asturian Basin. The Cenozoic activity of the Leon Fault is, on the contrary, less constrained. In this sense, however, meso- (Fig. 17) and macrostructures (Fig. 18a) in the area between the Duero Frontal Thrust and the Leon Fault indicate the existence of an important right-lateral pattern, of which the Leon Fault forms part (Fig. 18a, c). This is well-evident when analysing data collected in both Middle to Late Carboniferous syn to post-orogenic deposits and pre-Hercynian rocks (Fig. 17). Mesostructures in the area, in fact, are characterised by abundant right-lateral faults. Two extensional patterns are also recognisable in syn to late orogenic sediments, with WNWESE and NNW-SSE striking joints and rotaxes (i.e. rotational axis or slip-normal axis) of normal faults testifying for two extensional stages characterised by NNE-SSW and WSWENE oriented stretching directions, respectively. It was not possible to determine the relative chronology between these extensional events, whereas abundant right-lateral reactivation of WNW-ESE extensional elements is observed (Carola et al., 2012). As previously pointed out by Heredia (1998), which described a pervasive right-lateral pattern in the area, timing of right-lateral tectonics in the southern portion of the Cantabrian Mountains (i.e. between the Duero Frontal Thrust and the Leon Fault) cannot be fully constrained. However, the well-constrained Cenozoic age of right-lateral movements, along the Ventaniella Fault to the north and along the Ubierna Fault to the east, and fracture patterns seen on Cenozoic sediments of the Duero Basin (Fig. 18b) indicate a Cenozoic age for part of the right-lateral strike-slip assemblages of the area.

\section{Discussion}

\subsection{The Cenozoic orogeny}

In the following subsections, it will be illustrated how presented data support the conclusions that (1) the central and eastern Cantabrian areas formed a single belt, differentiating from the Pyrenean realm, where mountain building was associated with lower crust indentation. Such a proto Cantabrian belt was flanked to the south by a proto Duero Foreland Basin that included the Plataforma Burgalesa domain. (2) Both the Cantabrian belt and its associated foredeep-forebulge system nucleated to the north of their present-day position, migrated southward, and were later disarticulated by the right-lateral reactivation of the Ubierna and Ventaniella faults. (3) Contextually with the onset of right-lateral wrench tectonics, thin-skinned thrusts of the Pyrenean belt propagated westward, and progressively incorporated the north-eastern area of the proto Duero Foreland Basin. (4) Coeval right-lateral strike-slip tectonics to the west and thin-skinned tectonics to the east determined an intrabelt lateral extrusion, which led to the fusion of the two belts into a single orogen. (5) Strikeslip wrench tectonics in the Cantabrian belt is part of a wider intraplate deformation, which developed to accommodate a space problem arising from the distinct orogenic shortening directions in the Pyrenean and Cantabrian domains.

\subsubsection{The proto Cantabrian belt}

As illustrated in Fig. 2, indenting of the lower crust is wellrecognisable beneath the central and eastern Cantabrian belt (Pedreira et al., 2007) and, in both areas, the thickness of the indenting lower crustal body displays a first-order proportionality with the topographic elevation. This forms part of a wider set of evidence indicating that the central and eastern Cantabrian areas developed as a unique belt (differentiating from the Pyrenean realm located to the east), where Cenozoic mountain building was associated with lower crust indentation. This idea is fully supported by the following additional evidence, pointing out the limited internal deformation of both domains and their similar cross-sectional geometry: (1) in both areas, the first-order pre-orogenic architecture is well-preserved, both in terms of major structures 


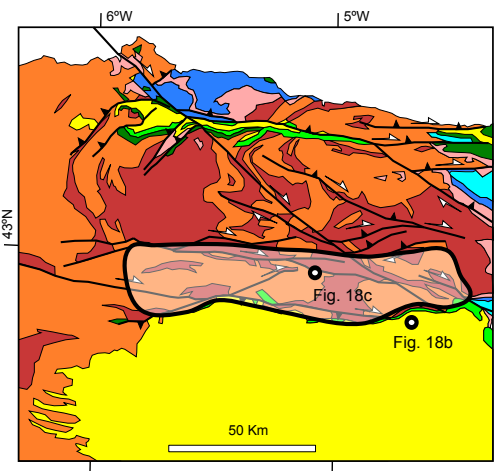

Cambrian to lower Carboniferous
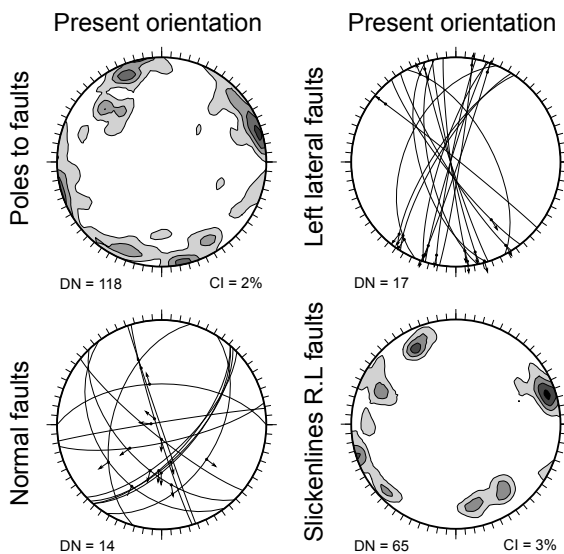

\section{Middle to upper Carboniferous}
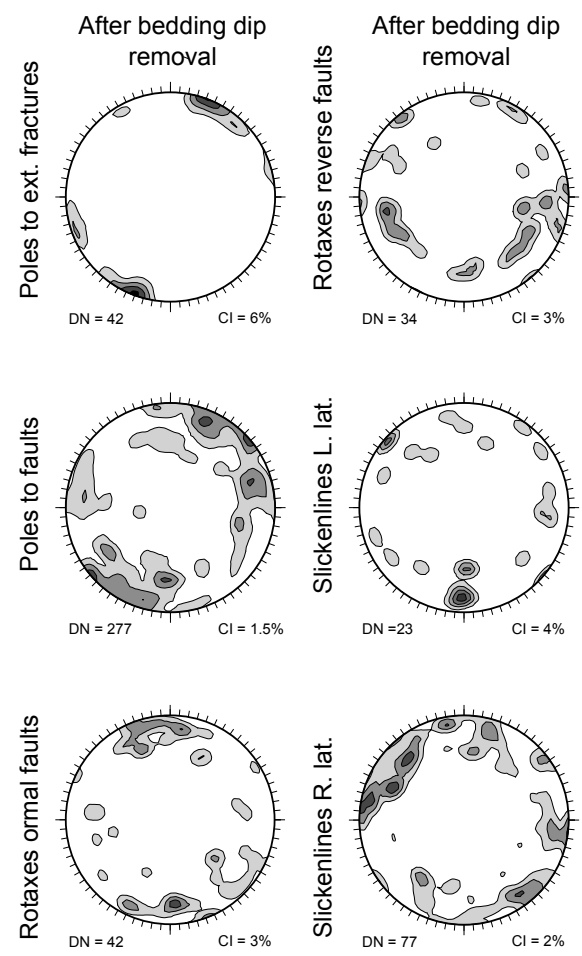

Fig. 17. Mesostructural data collected in Paleozoic rock of the Cantabrian belt.

and of diffuse background fracture patterns. In fact, Cenozoic mesostructures have been found only near major reactivated faults. Moreover, at a bigger scale of observation, the contractional deformation has produced the reactivation of major faults and, as seen in the Rumaceo and Golobar areas, it has produced also folding and/or re-folding of layers. However, with the exception of the Ubierna, Ventaniella, Leon, and Duero faults, the amount of admissible Cenozoic displacement along inherited faults generally does not exceed $1 \mathrm{~km}$. (2) In both areas, an uplifted sector overlying the thickened indenting lower crust exists, which is bounded to the south by a south-dipping limb. In the central Cantabrian belt it is the northern limb of the Duero Basin, which in map view has a slightly northward concave shape and is well-recognisable until it joins the Ubierna Fault (seismic lines $d$ to $f$ in Fig. 10). The Valmaseda monocline, bounding to the south the eastern Cantabrian belt, represents the natural northeastern prosecution of the northern limb of the Duero Basin. Between these two sectors of a formerly unique limb, the area between the Ubierna and Rumaceo faults represents a "perturbation zone", whose origin is discussed later. An independent additional datum supporting the existence of an early northward concave proto-Cantabrian belt is provided by mesostructures hosted in Upper Cretaceous limestones exposed in the Villarcayo syncline and in the Plataforma Burgalesa domain. Mesostructures indicate that these two areas underwent a common early-orogenic deformation (Fig. 12) (Quintà and Tavani, 2012). There, extensional structures that developed due to outer-arc extension in the peripheral bulge were overprinted by deformation structures formed due to along-strike stretching in the foredeep. For both areas, and for both events, mesostructures indicate a forebulge-foredeep system oriented WSW-ENE, i.e. exactly parallel to the strike of the Valmaseda monocline. Above-presented evidence supports the existence, before the right-lateral reactivation of the Ubierna-Ventaniella Fault System, of a unique proto Cantabrian belt flanking to the north a proto-Duero Foreland Basin, which included the Plataforma Burgalesa domain and the Villarcayo syncline areas (Fig. 19).

\subsubsection{From the proto Cantabrian belt to the present-day Cantabrian belt}

The presence of the above-discussed early-orogenic forebulge-related extensional assemblages several $\mathrm{km}$ to the north of the present-day position of the forebulge indicates that a southward migration of the latter has occurred (Fig. 19). This is consistent with the stratigraphic record of the Duero Basin, which started to act as foredeep at least 


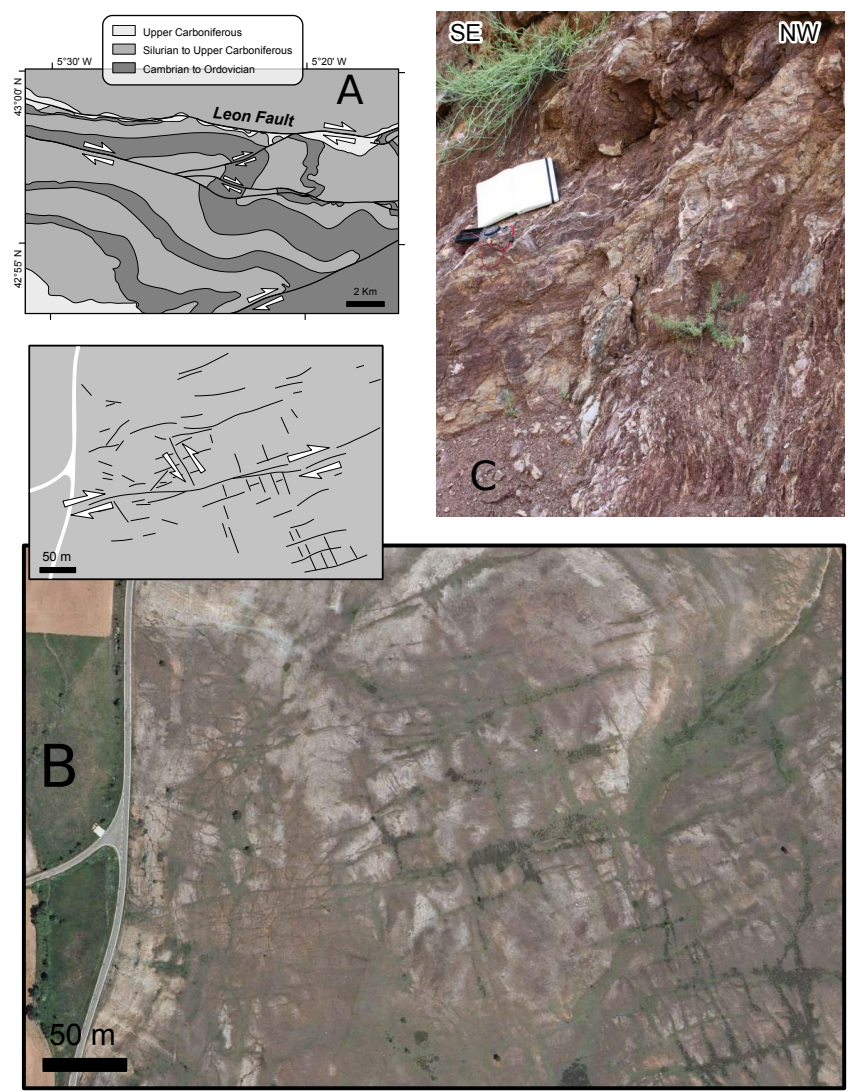

Fig. 18. (A) Schematic geological map in the area to the south of the Leon Fault. (B) Orthophoto and line-drawing of an area of the Duero Basin (see Fig. 18 for location) where subhorizontal Cenozoic layers are exposed. NNW-SSE and WSW-ENE striking fracture traces may correspond to early-orogenic extensional assemblages, which have been documented to the east by Quintà and Tavani (2012). These are postdated by an about E-W striking fault, whose right-lateral kinematics is well-constrained by its antithetic left-lateral fault. (C) Right-lateral calcite slickenlines along a - the Leon Fault System.

during Middle to Late Eocene (Alonso et al., 1996; Santisteban et al., 1996; Gallastegui, 2000) and where a progressive southward migration of Cenozoic depocentres has been documented (Herrero et al., 2004). These data support the hypothesis of Gallastegui (2000), who indicated that indentation of the lower crust started about $100 \mathrm{~km}$ to the north of the present-day position of the Duero Frontal Thrust. In light of above-presented evidence, the about $90 \mathrm{~km}$ of shortening proposed by Gallastegui (2002) for the Cantabrian portion of the orogen appears to be strongly congruent. Consistently with the foreland-ward migration of both early-orogenic deformation domains and foredeep depocentres, in the study area early-orogenic extensional stages were followed by a NNW-SSE oriented layer parallel shortening event (Quintà and Tavani, 2012), which caused the right-lateral reactivation of inherited WNW-ESE striking faults, including the
Ubierna-Ventaniella Fault System, and the development of WSW-ENE striking compressional structures, including the Huidobro anticline of the Plataforma Burgalesa domain. Apatite fission track thermochronology in the western termination of the Cantabrian Mountains mostly provides pre-Cenozoic ages (Grobe et al., 2010), indicating that the Cenozoic uplift was there accompanied by a limited denudation. Conversely, preliminary data from the central portion of the Cantabrian Mountains register the Cenozoic exhumation, which mostly occurred in Oligocene-Early Miocene age (Fillon et al., 2011). Growth strata associated with folds in the Ubierna Fault System are Oligocene too (Espina et al., 1996b). This allows to assume that early-orogenic extensional assemblages developed before Oligocene, while layer parallel shortening and right-lateral wrench tectonics, which were suitably coeval with the uplift of the Cantabrian Mountains, did not start earlier than Early Oligocene. A Late Oligocene age is indicated for the central portion of the Sierra de Cantabria Thrust (Portero et al., 1979; MuñozJimenez and Casas-Sainz, 1997), while the same thrust is Early to Middle Miocene in age in its western portion (Olivè Davò et al., 1978), where growth strata associated with the Oña anticline host tilted conjugate reverse faults indicating a roughly N-S oriented syn-folding compression (Tavani et al., 2011a). Few km to the north of this anticline, Quintà and Tavani (2012) documented the dip-slip reverse reactivation of WNW-ESE striking inherited faults, which previously have reactivated as right-lateral elements. This information proves that until Middle Miocene the Plataforma Burgalesa domain and the Villarcayo syncline formed a unique crustal block, belonging to the foreland basin of the Cantabrian domain, where right-lateral tectonics occurred along WNWESE striking inherited faults (Fig. 19). Breaking of the Cantabrian belt and of its associated proto-Duero Foreland Basin occurred during this stage (Fig. 19). ESE-directed movements in the northern block of the Ubierna Fault caused the positive inversion of NW-dipping inherited transversal extensional structures of the Plataforma Burgalesa domain (namely Ayoluengo, Hontomín and Rojas transversal faults), which resulted in the uplift of this domain. With increasing contraction, the Sierra de Cantabria Thrust Sheet moved southward (considering a fixed foreland) and, contextually, propagated westward incorporating the formerly eastern sector of the Proto-Duero Foreland Basin (Fig. 19).

\subsubsection{The westward propagation of the Pyrenean belt}

As mentioned in the corresponding section, the interpretation of the Sierra de Cantabria Thrust Sheet as resulting from the reactivation of a single extensional fault system is poorly consistent with the observed sharp lateral decreasing of its displacement. A consistent interpretation, reconciling all the available data in that area, is presented in the right column of Fig. 19, and implies that this thrust sheet resulted from the joining of two inversion-related anticlinal 

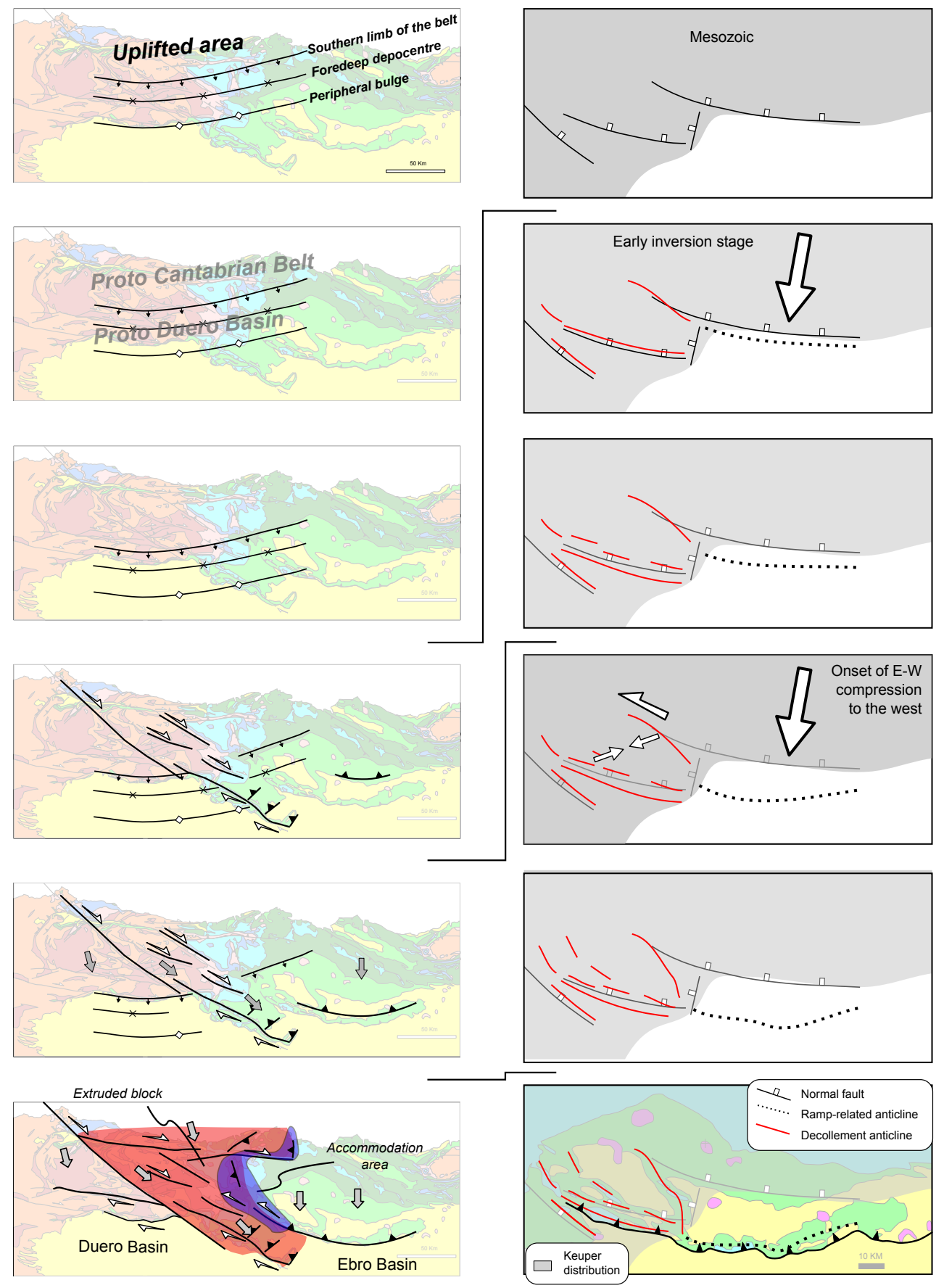

Fig. 19. Schematic Cenozoic evolution of the area (left), with detail of the Sierra de Cantabria Thrust Sheet (right).

systems, which developed due to the positive inversion of distinct and formerly distant WNW-ESE striking Mesozoic extensional fault systems. These extensional faults controlled the distribution of the ductile Triassic evaporitic level that, in turn, controlled the style of deformation during the inversion stage. In the proposed interpretation, the eastern portion of the thrust sheet resulted from ramp-related folding (Suppe, 1983; Suppe and Medwedeff, 1990; Tavani and Storti, 2006), as immediately to the south of the inverted fault the Triassic evaporites were not present. Conversely, to the east the limit of Keuper evaporites was located in a southernmost position (i.e. the Ubierna Fault area). Shortening in this western area was mostly accommodated by décollement folding (e.g. Chamberlin, 1910; Buxtorf, 1916; Jamison, 1987), which allowed for the development of a higher number of anticlines distributed along a wider cross-sectional zone, which 
is a typical behaviour in presence of a ductile décollement level (e.g. Lujan et al., 2003). The Pancorbo Transversal System, which divides the two areas of the Sierra de Cantabria Thrust Sheet, is here interpreted as an accommodation structure resulting from the reactivation of an inherited transversal extensional element, which laterally delimited the Keuper facies during Mesozoic. The proposed interpretation implies a smoothed westward decreasing of the cumulative displacement, which to the west was accommodated by multiple structures. Coherently with this, it must be assumed that the Sierra de Cantabria Thrust is a late-stage thrust fault, resulting from the linkage of formerly distant fault systems. It is worth highlighting that the Keuper evaporites are exposed several $\mathrm{km}$ to the north of the Plataforma Burgalesa domain, near the Cabuérniga Fault. The trace of this E-W striking fault is not offset across evaporites, noting how, similarly to what was observed in the Rumaceo and Golobar area, in this portion of the belt the Triassic evaporites did not act as an important Cenozoic décollement level. From this, it arises that the N-S oriented shortening accommodated by folds of the western portion of the Sierra de Cantabria Thrust Sheet must have been transmitted to the north to a deeper décollement level. Consequently, the Valmaseda monocline is probably affected at depth by few reverse north-dipping faults, similar to those of the northern limb of the Duero Foreland Basin.

\subsubsection{Extrusion tectonics and the joining of the Cantabrian and Pyrenean belts}

The coexistence of right-lateral movements along the WNW-ESE striking Ubierna-Ventaniella Fault System and of reverse south-directed movements along the Sierra de Cantabria Thrust imposed "space" problems for crustal sectors involved in the orogenic process, causing the onset of an intrabelt E-W oriented compression (Fig. 19) (Tavani et al., 2011a). The question is rather simple and arises from the following geometrical consideration: assuming a fixed foreland, SE- to SSE-directed movements in the crustal block to the north of the Ubierna Fault can be decomposed into southand east-directed components. The south-directed component can be reasonably assumed to have been partially compensated by the south-directed movements along the western portion of the Sierra de Cantabria Trust Sheet (which explains also the reduced amount of shortening in the fold systems of the western potion of the Sierra de Cantabria Thrust Sheet). Conversely, the east-directed component was not compensated, thus imposed an E-W shortening associated with a relative (with respect to the Basque Pyrenees) eastward extrusion of the western portion of the Cantabrian belt and of the Plataforma Burgalesa domain. Abundant WNWESE striking left-lateral faults affecting Upper Cretaceous limestones in the southern limb of the Villarcayo syncline, and postdating all the other assemblages (Quintà and Tavani, 2012), as well as left-lateral reactivation of the WNW-ESE striking Rumaceo and Golobar faults, and the WNW-ESE striking left-lateral transpressive fault zone in the core of the Oña anticline (Tavani et al., 2011a) fully support the existence of this E-W compression, as well as do the N-S striking Pas and Ramales anticlines, which according to Tavani et al. (2011a) formed within the framework of the extrusion tectonics. Reverse mesofaults hosted in the Early to Middle Miocene growth strata of the Oña anticline indicate that extrusion tectonics did not start earlier than Middle Miocene. Proving the validity of the entire framework requires documenting right-lateral movements along the E-W Cabuérniga Fault, which should have formed the northern portion of the accommodation zone. In this work, this evidence has been presented. Summarising, the entire Cantabrian Transitional Area is a complex accommodation zone, across which the south-verging portion of the Pyrenean orogen experienced a strong decreasing of south-directed orogenic shortening. In such a framework, a belt-perpendicular tear fault or tear fault zone is to be expected, which actually is present in the northverging portion of the orogen (Figs. 1a, 2). Conversely, in the Cantabrian Transitional Area, the Cenozoic tectonic framework was moulded by several inherited fault sets, which prevented the development of a unique and simple right-lateral tear system.

\subsubsection{Right-lateral wrench tectonics and intraplate deformation}

Data presented in this work indicate that important rightlateral wrench tectonics occurred also in the southern portion of the central Cantabrian belt, along the Ventaniella Fault and in the area between the Leon Fault and Duero Frontal Thrust. This supports the early hypothesis of Tavani et al. (2011a), who suggested that the $15 \mathrm{~km}$ of right-lateral displacement computed along the Ubierna Fault to the west have been transferred to the above-cited three major structures. However, while the amount of right-lateral displacement along the central portion of the Ventaniella Fault (i.e. about $4 \mathrm{~km}$, Alvarez-Marrón, 1995) is consistent with this scenario, assuming a cumulative Cenozoic right-lateral displacement of about $10 \mathrm{~km}$ for the Leon Fault and the Duero Frontal Thrust is not reasonable. This implies that a westward decreasing of the right-lateral displacement must be assumed. Contextually, in the western termination of the Cantabrian Mountain Range, the number of strike-slip structures consistent with an about NNW-SSE oriented shortening increases. NW-SE to WNW-ESE striking right-lateral faults and N-S to NNE-SSW striking left-lateral faults, in fact, are abundant in the western portion of the Iberian Peninsula, which is also characterised by the presence of other intraplate Cenozoic structures (Fig. 20) (e.g. Cunha and Pereira, 2000; Guimerà et al., 2004; De Vicente et al., 2011; and references therein). Despite the ongoing debate about the detailed evolution of the Cenozoic intraplate stress fields of the area (e.g. Liesa and Simón-Gomez, 2007; De Vicente et al., 2009), it is pretty evident that WNW-ESE striking 


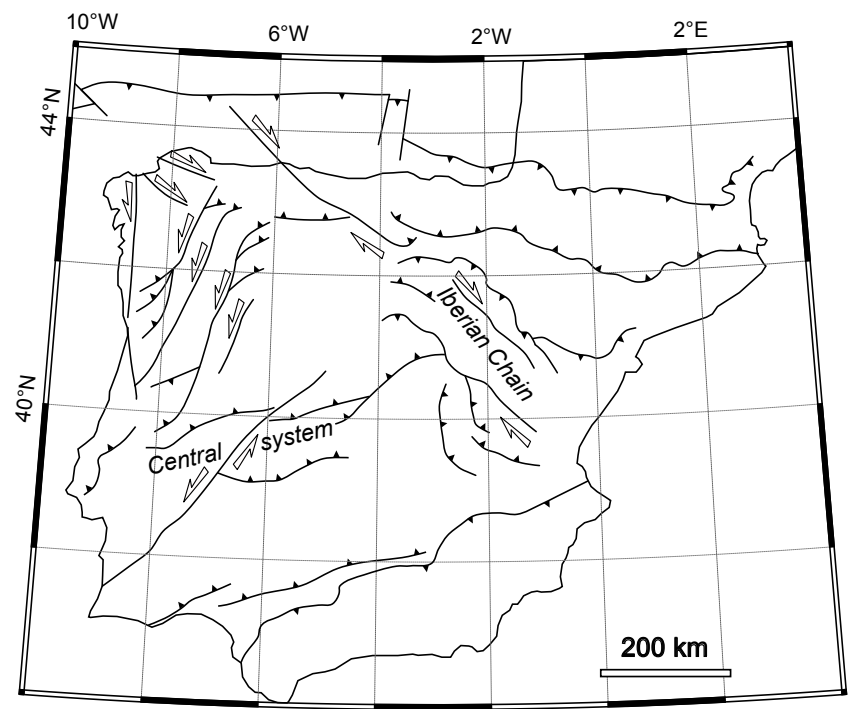

Fig. 20. Cenozoic tectonic sketch map of the Iberian Peninsula (after De Vicente et al., 2009).

right-lateral faults and N-S to NNE-SSW striking left-lateral faults of the western portion of the Iberian peninsula, together with the WSW-ENE striking Central System, fit well into an about NNW-SSE oriented compression (Pais, 2012 and references therein), which is the Cenozoic layer parallel shortening direction documented for the Cantabrian Mountains (Quintà and Tavani, 2012). The eastern boundary of these intraplate elements is provided by the Iberian Chain, for which a complex Cenozoic partitioning between strikeslip and reverse movements has been recognised. In particular, De Vicente et al. $(2009,2011)$ documented a Cenozoic right-lateral strike-slip component along NW-SE oriented elements, which roughly core the chain. Contextually, these authors found a Pyrenean NNE-directed tectonic transport direction in the north-eastern sector of this chain, while reverse faults become west-verging in the western areas. Finally, Cenozoic transport direction turns into north-verging in the northern tip of the chain (De Vicente et al., 2009). This northern tip is separated by the exposed southeastern termination of the Ubierna-Ventaniella Fault System by less than $10 \mathrm{~km}$. In the area between these elements, several Cenozoic basement structures have been recognised in seismic sections (Hernáiz Huerta and Solé Pont, 2000), being the San Pedro structural highs the most prominent. All the above-discussed intraplate features can be explained in the framework of a non-rigid behaviour of Iberia during Pyrenean orogeny. In fact, N-S to NNE-SSW and NNW-SSE oriented shortening in the Pyrenean and Cantabrian realms, respectively, do not allow to be describe the Cenozoic motion of Iberia by rotation about a single Euler pole. It is here proposed that the intraplate structures of Iberia, including the Ubierna Fault System and the Iberian Chain, developed to accommodate the intraplate space problems resulting from the different short- ening directions in the western and eastern portions of the Pyrenean orogen.

\subsection{The Mesozoic rifting stage}

The Mesozoic history recorded in the study area is characterised by a simpler framework with respect to the Cenozoic one. The presence of much evidence of left lateral movements along WNW-ESE and NW-SE striking faults, which mimics a left-lateral strike slip system, probably stands behind the hypothesis of the existence of an Aptian-Albian left-lateral tectonic stage in the study area (García-Mondéjar, 1996). This hypothesis, however, is confuted by the following evidence: (1) WNW-ESE left-lateral movements in the area affect the entire sedimentary package, up to Upper Cretaceous limestones, postdating Miocene thrusting and folding (Quintà and Tavani, 2012); (2) computed stretching direction during Mesozoic rifting in the Basque Cantabrian Basin was about NNE-SSW (Tavani and Muñoz, 2012); (3) this stretching direction is parallel to a set of regionalscale Mesozoic faults that segmented the Bay of BiscayPyrenean rift system, among which the most important ones are the Santander and Pamplona fault zones which bounded the Basque-Cantabrian Basin to the west and to the east, respectively (Fig. 1a) (e.g. Roca et al., 2011); (4) a Mesozoic NNE-SSW oriented stretching direction is also observed in the Organyà Basin, which is located in the Pyrenean Mountain Range and belongs to the western portion of the Bay of Biscay-Pyrenean rift system. In agreement with these observations, all of them showing an almost ridge-perpendicular (i.e. about NNE-SSW) stretching direction during the opening of the Bay of Biscay, the only doubtful structure presented in this work, which is the NE-SW striking left-lateral transtensive Selaya Fault System, can be easily interpreted in the framework of NNE-SSW oriented stretching. A consistent interpretation for the structural pattern observed along this fault zone, in fact, is that NE-SW and NW-SE oriented extensional structures of this area, as well as the Selaya Fault System itself, originally developed as either synthetic relay ramp or antithetic extensional interference zones (Gawthorpe and Hurst, 1993), linking the western termination of the Cabuérniga Fault and another extensional fault located more to the south (and today buried below Upper Cretaceous limestones). This former transfer zone would have been later incorporated into the hanging wall of the Cabuérniga Fault, and thus underwent a WNW-ESE oriented extension, caused by along-strike stretching (e.g. Destro, 1995), which led to the left-lateral transtensive reactivation of the inherited NE-SW striking faults.

\subsection{Initiation of subduction in the Cantabrian domain}

Subduction initiation is one of the most important and partially unsolved problem of plate tectonics, mostly due to the lack of unambiguous examples. Despite the fact that 


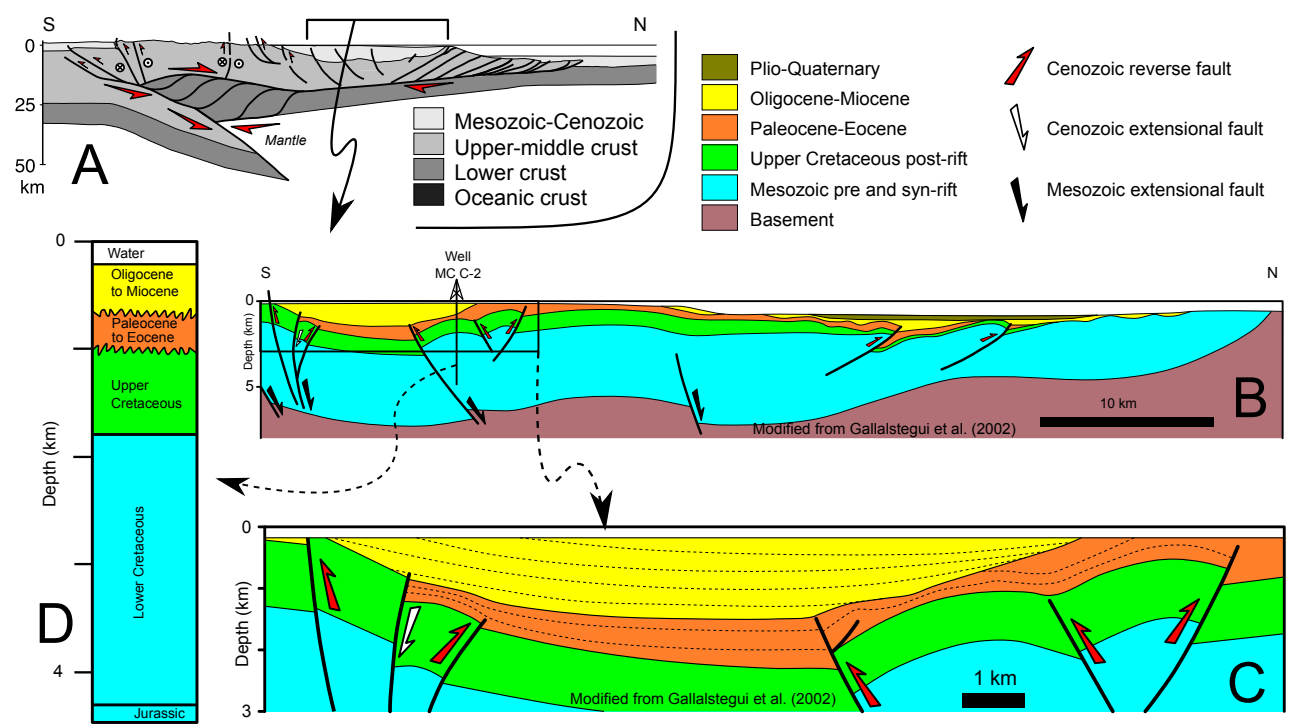

Fig. 21. (A) Crustal-scale geological cross section P3 of Fig. 2 (modified from Gallastegui, 2000 and Quintà and Tavani, 2012). (B-C) Geological cross section across the Cantabrian platform (modified from Gallastegui et al., 2002). (D) Stratigraphy of well MC C2 (After Gallastegui, 2000).

Cantabrian domain is a very atypical subduction zone, here it is proposed that it represents one of the few sites in the world where the entire orogenic process, including the subduction nucleation stage, is well-recorded. As previously pointed out, both the stratigraphic (e.g. Herrero et al., 2004) and the structural record (Quintà and Tavani, 2012) in the Cantabrian pro-wedge indicate that the foredeep-forebulge system has progressively migrated southward, consistent with the interpretation of Gallastegui (2000), who indicated that subduction and related indentation of the lower crust started about $100 \mathrm{~km}$ to the north of the present-day position of the Duero Foreland Basin. That area is the Iberian platform that, accordingly, should host evidence of how upper crustal levels respond to subduction initiation. The N-S oriented geological cross sections in Fig. 21 show how that area corresponds to a Mesozoic passive continental margin that underwent limited Cenozoic inversion (Gallastegui et al., 2002). Despite the presence of many reverse faults and associated anticlines, it can be recognised the presence of an about 40-km-wide syncline filled by Paleocene to Eocene strata (Gutiérrez Claverol and Gallastegui, 2002). These sediments reach a thickness of $1 \mathrm{~km}$ in the core of the syncline, where they conformably overlie the Mesozoic sequence, whereas they progressively onlap both to the north and to the south, at the northern and southern edge of the syncline, respectively. This is particularly evident in the southern portion of the section (Fig. 21c), where a formerly extensional fault bounds to the south the Paleocene to Eocene syn-kinematic sediments. Deposition of Eocene and even Paleocene sediments was thus coeval with the development of the syncline, which accordingly had to predate the development of the Duero Foreland Basin and also the uplift of the Cantabrian Mountains, both of which did not start earlier than Middle Eocene time (Alonso et al., 1996; Santisteban et al., 1996; Herrero et al., 2004; Fillon et al., 2011). All this evidence indicates that the progressive southward migration of the foredeep-peripheral bulge system of the Cantabrian pro-wedge started in the area shown in Fig. 21b, at least during the Paleocene. In other words, the unconformity between Paleocene and Upper Cretaceous sediments found in the MC C-2 well (Fig. 21d) and the geometries of Fig. 21b-c indicate that mountain building associated with indentation of the lower crust was anticipated by the development of a today well-preserved lithospheric-scale syncline, which divided the future pro- and retro-wedge. This allows to conclude that, despite some complications and the atypical subduction framework of the belt, the geometries observed in Fig. 21b actually represent an outstandingly preserved image of what beginning of subduction induces in the upper crustal levels, being in essence a lithospheric-scale and low-amplitude syncline overlying the nucleation point of subduction (Fig. 22). This syncline can be interpreted as induced by the triggering, at a very low value of the orogenic shortening, of a gravitational instability leading to the collapse of the lithosphere into the asthenosphere (e.g. Stern, 2004), which would have implied the development of a rather symmetric and downward amplifying syncline. The excess length in the crust was asymmetrically accommodated by the reactivation of the inherited extensional detachment (e.g. Gallastegui et al., 2002; Roca et al., 2011; Fernández-Viejo et al., 2012), above which the first embryonic contractional structures of the retro-wedge developed. It is worth remarking that, in a map view, the northward concave shape of all the structural features of the Cantabrian domain (Fig. 19) imposes a subduction nucleation approximately located in the 

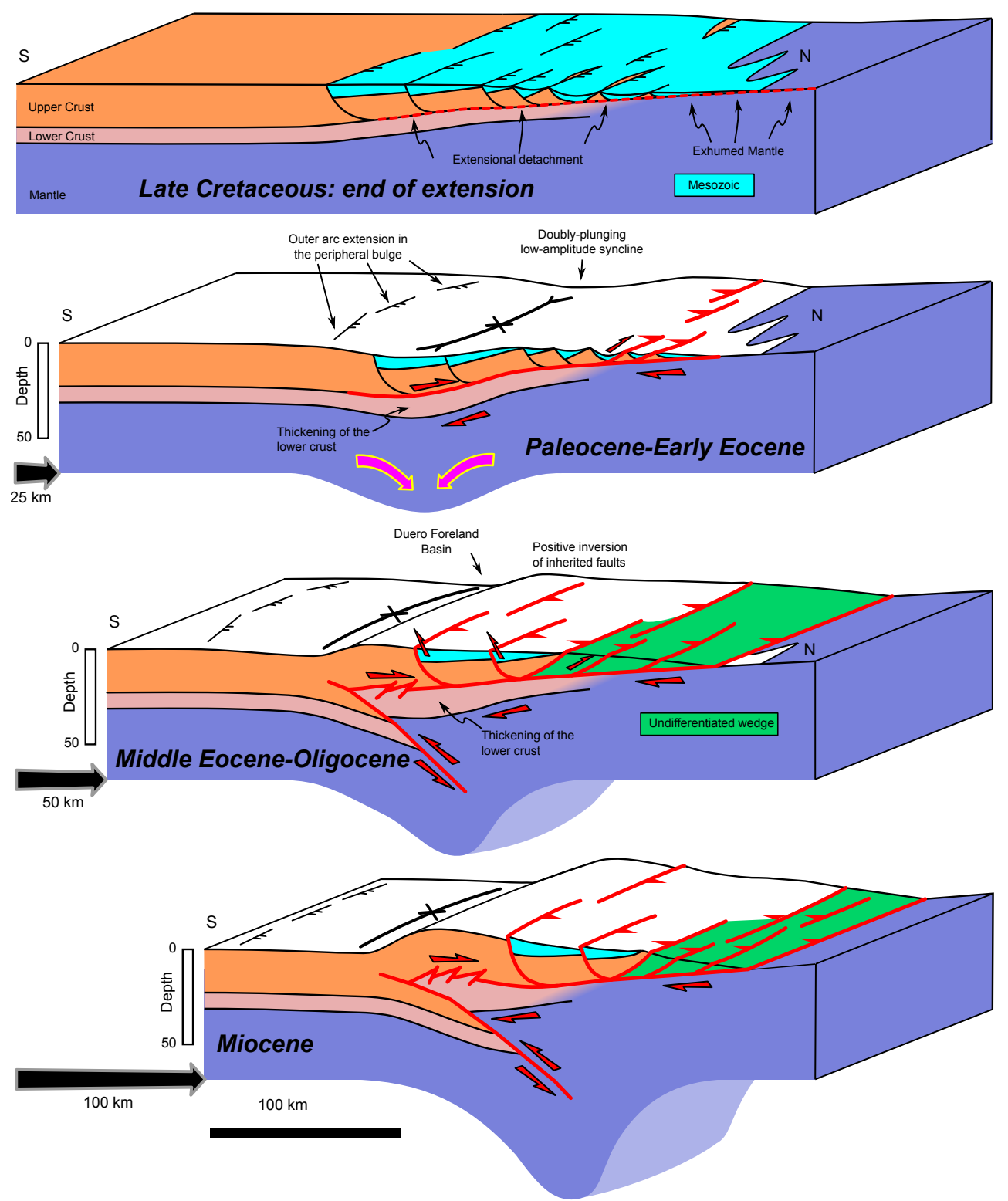

Fig. 22. Schematic evolution of subduction and development of the Pyrenean orogen in the Cantabrian domain.

area of Fig. 21b-c, which would have propagated both westward and eastward. This rules out any influence of the eastern Pyrenean domain, where subduction started in the Late Cretaceous (e.g. Beaumont et al., 2000), in determining subduction nucleation in the Cantabrian domain. Conversely, the westward propagation of the eastern, north-directed, Pyrenean lithospheric architecture influenced the subsequent step of deformation, when the symmetric mantle syncline was forced toward a north-verging framework. This implies continuous lower crust thickening and the consequent Middle Eocene to Miocene uplift of the Cantabrian Mountains, with the development of the two foredeep basins associated with flexure of the lithosphere.

\section{Conclusions}

The doubly vergent Pyrenean orogen represents the boundary between the Iberian and Eurasian plates and extends from the Atlantic Ocean to the Mediterranean Sea. It includes two distinct domains developed due to the subduction of the Iberian Plate underneath the Eurasian one. The Pyrenean domain to the east includes the Pyrenean Mountain Ranges and the Basque area and, in its south-verging portion, it is characterised by far-travelled thin-skinned frontal structures. In the Cantabrian domain to the west, mountain building was associated with indenting and associated thickening of the lower crust, which caused uplift with limited 
internal deformation of the Cantabrian Mountains. Orogenic shortening in this domain was almost entirely accommodated in the northern retro-verging portion of the orogen. The Cantabrian Transitional Area represents the transition between these two domains. The northern portion of this area formed part of the Cantabrian domain during the entire orogenic process. The southern area during the early stages of mountain building represented in the eastern portion of the foreland basin flanking to the south the Cantabrian domain. In a subsequent stage, the westward propagation of thinskinned structures belonging to the eastern domain of the Pyrenean orogen caused the incorporation of the southeastern part of the Cantabrian Transitional Area into the Pyrenean domain. Contextually, onset of right-lateral strike-slip tectonics along the WNW-ESE striking Ubierna-Ventaniella Fault System disarticulated the geometry of the Cantabrian belt and of its associated foredeep. Coexistence of rightlateral and reverse movements to the west and to the east, respectively, determined the onset of an intrabelt compression at the boundary between the Cantabrian and Pyrenean domains, which was the ultimate act of the fusion of the two domains into a single orogen. The Ubierna Fault System, which has been interpreted in the past as the leading edge of thin-skinned contractional deformation of the Pyrenean orogen in the Cantabrian area, has to be regarded as part of thick-skinned intraplate strike-slip deformation, which developed to accommodate intraplate space problems resulting from different orogenic shortening directions in the Pyrenean and Cantabrian domains

Presented data, together with a reappraisal of available information, indicate that the Cantabrian area is one of the few natural examples where mechanisms operating during beginning of subduction are outstandingly preserved. In particular, it is proposed that convergence induced the triggering of a gravitational instability, which determined the development a regional-scale syncline overlying embryonic lithosphere sinking. With increasing convergence, reactivation of an inherited extensional décollement has determined the development of a retro-wedge, with coeval indentation tectonics and lower crust thickening in the poorly-developed pro-wedge.

Acknowledgements. I would like to sincerely thank J. A. Muñoz, E. Roca, P. Granado, A. Quintà, E. Carola, and O. Ferrer for fruitful discussions that inspired this paper. An early version of this paper benefited from critical reviews by Jeroen van Hunen and two anonymous reviewers. This work was carried out under the financial support of CIUDEN (FBG305657). I thank the I.G.N. (INSTITUTO GEOGRÁFICO NACIONAL DE ESPAÑA) and the I.G.M.E. (INSTITUTO GEOLÓGICO Y MINERO DE ESPAÑA) for providing orthophotos and seismic sections and geological maps, respectively.

Special Issue: "Subduction zones"

Edited by: S. Buiter, F. Funiciello, and J. van Hunen

\section{References}

Ábalos, B., Alkorta, A., and Iríbar, V.: Geological and isotopic constraints on the structure of the Bilbao anticlinorium (BasqueCantabrian basin, North Spain), J. Struct. Geol., 30, 1354-1367, doi:10.1016/j.jsg.2008.07.008, 2008.

Alonso, J. L., Pulgar, F. J., García-Ramos, J. C., and Barba, P.: Tertiary Basins and Alpine Tectonics in the Cantabrian Mountains, in: Tertiary basins of Spain: The stratigraphic record of crustal kinematics, edited by: Friend, P. F. and Dabrio, C. J., Cambridge University Press, Cambridge, 214-227, 1996.

Alonso, J. L., Marcos, A., and Suárez, A.: Paleogeographic inversion resulting from large out of sequence breaching thrusts: The León Fault (Cantabrian Zone, NW Iberia). A new picture of the external Variscan Thrust Belt in the Ibero-Armorican Arc, Geol. Acta, 7, 451-473, doi:10.1344/105.000001449, 2009.

Alvarez-Marrón, J.: Three-dimensional geometry and interference of fault-bend folds: examples from the Ponga Unit, Variscan Belt, NW Spain, J. Struct. Geol., 17, 549-560, doi:10.1016/01918141(94)00075-B, 1995.

Alvarez-Marrón, J., Rubio, J., and Torné, M.: Subduction-related structures in the North Iberian Margin, J. Geophys. Res., 102, 22497-22511, doi:10.1029/97JB01425, 1997.

Ayarza, P., Martínez Catalán, J. R., Gallart, J., Pulgar, J. A., and Dañobeitia, J. J.: Estudio Sísmico de la Corteza Ibérica Norte 3.3: A seismic image of the Variscan crust in the hinterland of the NW Iberian Massif, Tectonics, 18, 171-186, doi:10.1029/97TC03411, 1998.

Beaumont, C., Munoz, J. A., Hamilton, J., and Fullsack, P.: Factors controlling the Alpine evolution of the central Pyrenees inferred from a comparison of observations and geodynamical models, J. Geophys. Res., 105, 8121-8145, doi:10.1029/1999JB900390, 2000.

Beroiz, C. and Permanyer, A.: Hydrocarbon habitat of the Sedano Trough, Basque-Cantabrian Basin, Spain, J. Petrol. Geol., 34, 387-410, doi:10.1111/j.1747-5457.2011.00511.x, 2011

Boillot, G., Dupeuble, P. A., and Malod, J.: Subduction and tectonics on the continental margin off northern Spain, Mar. Geol., 32, 53-70, doi:10.1016/0025-3227(79)90146-4, 1979.

Boillot, G., Recq, M., Winterer, E. L., Meyer, A. W., Applegate, J., Baltuck, M., Bergen, J. A., Comas, M. C., Davies, T. A., Dunham, K., Evans, C. A., Girardeau, J., Goldberg, G., Haggerty, J., Jansa, L. F., Johnson, J. A., Kasahara, J., Loreau, J. P., Luna-Sierra, E., Moullade, M., Ogg, J., Sarti, M., Thurow, J., and Williamson, M.: Tectonic denudation of the upper mantle along passive margins: a model based on drilling results (ODP leg 103, western Galicia margin, Spain), Tectonophysics, 132, 335-342, doi:10.1016/0040-1951(87)90352-0, 1987.

Brown, R. N.: History of exploration and discovery of Morgan, Ramadan, and July oilfields, Gulf of Suez, Egypt, in: Facts and principles of world petroleum occurrence, edited by: Miall, A. D., Canadian Society of Petroleum Geologists Memoir, 6, 733-764, 1980.

Buxtorf, A.: Prognosen und Befunde beim Hauensteinbasis-und Grenchenburgtunnel und die Bedeutung der letzteren für die Geologie des Juragebirges, Verhandlungen Naturforschende Gesellschaft Basel, 27, 184-254, 1916.

Capitanio, F. A. And Goes, S.: Mesozoic spreading kinematics: consequences for Cenozoic Central and Western Mediterranean subduction, Geophys. J. Int., 165, 804-816, doi:10.1111/j.1365- 
246X.2006.02892.x, 2006.

Cámara, P.: The Basque-Cantabrian basin's Mesozoic tectonosedimentary evolution, Mém. Soc. Géol. France, 171, 187-191, 1997.

Carola, E., Ferrer, O., Granado, P., Quintà, A., Butillé, M., and Muñoz, J. A.: Along-strike extrusion at the transition between thin- and thick-skinned domains in the Pyrenean Orogen (northern Spain), in: Thick-Skin-Dominated Orogens: From Initial Inversion to Full Accretion, edited by: Nemcok, M. and Mora, A., Geological Society of London, Special Publication, accepted, 2012.

Chamberlin, R. T.: The Appalachian folds of central Pennsylvania, J. Geol., 18, 228-251, 1910.

Choukroune, P. and ECORS Team: The ECORS Pyrenean deep seismic profile reflection data and the overall structure of an orogenic belt, Tectonics, 8, 23-39, doi:10.1029/TC008i001p00023, 1989.

Cunha, P. P. and Pereira, D. I.: Evolução cenozóica da área de Longroiva-Vilariça (NE Portugal), Ciências da Terra, 14, 91100, 2000.

Dallmeyer, R. D., Martínez Catalán, J. R., Arenas, R., Gil Ibarguchi, J. I., Gutiérrez Alonso, G., Farias, P., Bastida, F., and Aller, J.: Diachronous Variscan tectonothermal activity in the NW Iberian Massif: evidence from ${ }^{40} \mathrm{Ar} /{ }^{39} \mathrm{Ar}$ dating of regional fabrics, Tectonophysics, 227, 307-337, doi:10.1016/S00401951(97)00035-8, 1997.

De Vicente, G., Vegas, R., Muñoz-Martín, A., Van Wees, J. D., Casas-Sáinz, A., Sopeña, A., Sánchez-Moya, Y., Arche, A., López-Gómez, J., Olaiz, A., and Fernández-Lozano, J.: Oblique strain partitioning and transpression on an inverted rift: The Castilian Branch of the Iberian Chain, Tectonophysics, 470, 224 242, doi:10.1016/j.tecto.2008.11.003, 2009.

De Vicente, G., Cloetingh, S., Van Wees, J. D., and Cunha, P. P.: Tectonic classification of Cenozoic Iberian foreland basins, Tectonophysics, 502, 38-61, doi:10.1016/j.tecto.2011.02.007, 2011.

Destro, N.: Release fault: a variety of cross fault in linked extensional fault systems, in the Sergipe-Alagoas Basin, NE Brazil, J. Struct. Geol., 17, 615-629, doi:10.1016/0191-8141(94)00088-H, 1995.

Espina, R. G.: La estructura y evolución tectonoestratigráfica del borde occidental de la Cuenca Vasco-Cantábrica (Cordillera Cantábrica, NO de España), Ph.D. thesis, Univerity of Oviedo, 230 pp., 1997.

Espina, R. G., De Vicente, G., and Muñoz Martín, A.: Análisi poblacional de fallas alpinas en el borde occidenteal de la Cuenca Vasco-Cantábrica (Cordillera Cantábrica, NO de España), Geogaceta, 20, 936-938, 1996a.

Espina, R. G., Alonso, J. L., and Pulgar, J. A.: Growth and propagation of buckle folds determined from syntectonic sediments (the Ubierna Fold Belt, Cantabrian Mountains, N Spain), J. Struct. Geol., 18, 431-441, 1996b.

Espina, R. G., Alonso, J. L., and Pulgar, J. A.: Extensión Triásica en la Cuenca Vasco-Cantábrica, in: Geología de España, edited by: Vera, J. A., SGE-IGME, Madrid, 338-339, 2004.

Fernández-Viejo, G., Gallart, J., Pulgar, J. A., Gallastegui, J., Dañobeitia, J. J., and Córdoba, D.: Crustal transition between continental and oceanic domains along the North Iberian margin from wide angle seismic and gravity data, Geophys. Res. Lett.,
25, 4249-4252, doi:10.1029/1998GL900149, 1998.

Fernández-Viejo, G., Pulgar, J. A., Gallastegui, J., and Quintana, L.: The Fossil Accretionary Wedge of the Bay of Biscay: Critical Wedge Analysis on Depth-Migrated Seismic Sections and Geodynamical Implications, J. Geol., 120, 315-331, doi:10.1086/664789, 2012.

Fillon, C., Barbero, L., Pedreira, D., Gautheron, C., and van der Beek, P.: Thermochronological evidence for significant Cenozoic exhumation in the Eastern Cantabrian Mountains, Geophys. Res. Abstr., 13, 5849, 2011.

Floquet, M.: El Cretácico Superior de la Cuenca Vasco-Cantábrica y áreas adyacentes, in: Geología de España, edited by: Vera, J. A., SGE-IGME, Madrid, 299-306, 2004.

Gallastegui, J.: Estructura cortical de la Cordillera y Margen Continental Cantábricos: Perfiles ESCI-N, Trabajos de Geología, 22, 9-234, 2000.

Gallastegui, J., Pulgar, J. A., and Gallart, J.: Initiation of an active margin at the North Iberian continent-ocean transition, Tectonics, 21, 1033, doi:10.1029/2001TC901046, 2002.

García-Mondéjar, J.: Plate reconstruction of the Bay of Biscay, Geology, 24, 635-638, doi:10.1130/00917613(1996)024<0635:PROTBO>2.3.CO;2, 1996.

García-Mondéjar, J., Pujalte, V., and Robles, S.: Características sedimentológicas, secuenciales y tectoestratigráficas del Triásico de Cantabria y Norte de Palencia, Cuadernos de Geología Ibérica, 10, 151-172, 1986.

García-Mondéjar, J., Agirrezabala, L. M., Aranburu, A., Fernández-Mendiola, P. A., Gómez-Pérez, I., López-Horgue, M., and Rosales, I.: Aptian-Albian tectonic pattern of the Basque-Cantabrian Basin (Northern Spain), Geol. J., 31, 13-45, doi:10.1002/(SICI)1099-1034(199603)31:1<13::AIDGJ689>3.0.CO;2-Y, 1996.

García Ramos, J. C., Colmenero, J. R., Vargas, I., Manjón, M. Crespo, A., and Matas, J.: Mapa Geológico de España 1:50.000, Sheet 132 (Guardo), IGME, Madrid, 1982.

Gawthorpe, R. L. and Hurst, J. M.: Transfer zones in extensional basins: their structural style and influence on drainage development and stratigraphy, J. Geol. Soc., 150, 1137-1152, doi:10.1144/gsjgs.150.6.1137, 1993.

Gómez, M., Vergés, J., and Riaza, C.: Inversion tectonics of the northern margin of the Basque Cantabrian Basin, B. Soc. Geol Fr., 173, 449-459, doi:10.2113/173.5.449, 2002.

Grobe, R. W., Alvarez-Marrón, J., Glasmacher, U. A., and Menéndez-Duarte, R.: Low-temperature exhumation history of Variscan-age rocks in the western Cantabrian Mountains (NW Spain) recorded by apatite fission-track data, Tectonophysics, 489, 76-90, doi:10.1016/j.tecto.2010.04.006, 2010.

Gross, M. R.: The origin and spacing of cross joints: examples from the Monterey Formation, Santa Barbara Coastline, California, J. Struct. Geol., 15, 737-751, doi:10.1016/0191-8141(93)90059-J, 1993.

Guimerà, J., Más, R., and Alonso, A.: Intraplate deformation in the NW Iberian Chain: Mesozoic extension and contractional inversion, J. Geol. Soc., 16, 291-303, doi:10.1144/0016-764903-055, 2004.

Gutiérrez-Alonso, G., Fernández-Suárez, J., Weil, A. B., Murphy, J. B., Nance, R. D., Corfú, F., and Johnston, S. T.: Selfsubduction of the Pangaean global plate, Nat. Geosci., 1, 549553, doi:10.1038/ngeo250, 2008. 
Gutiérrez Claverol, M. and Gallastegui, J.: Prospección de hidrocarburos en la plataforma continental asturiana, Trabajos de Geología, 23, 21-34, 2002.

Heredia, N.: Los Cabalgamientos del sector suroriental de las unidades del Ponga y de la Cuenca Carbonífera Central (Zona Cantábrica, NO de España), Trabajos de Geología, 20, 53-127, 1998.

Heredia, N., Alonso, J. L., and Rodrígues Fernández, L. R.: Mapa Geológico de España 1:50.000, Sheet 105 (Riaño), IGME, Madrid, 1990.

Hernáiz, P. P.: La falla de Ubierna (margen SO de la cuenca Cantábrica), Geogaceta, 16, 39-42, 1994.

Hernáiz, P. P. and Solé Pont, J.: Las estructuras del diapiro de Salinas del Rosío y del alto de San Pedro-Iglesias y sus implicaciones en la evolución tectónica de la transversal burgalesa de la Cordillera Vascocantábrica-Cuenca del Duero, Revista de la Sociedad Geológica de España, 13, 471-486, 2000.

Herrero, A., Alonso Gavilán, G., and Colmenero, J. R.: Estratigrafía del subsuelo en el sector noroeste de la cuenca del Duero (Provincia de León), Revista de la Sociedad Geológica de España, 17, 199-216, 2004.

Jamison, W. R.: Geometric analysis of fold development in overthrust terranes, J. Struct. Geol., 9, 207-219. doi:10.1016/01918141(87)90026-5, 1987.

Jammes, S., Manatschal, G., Lavier, L., and Masini, E.: Tectonosedimentary evolution related to extreme crustal thinning ahead of a propagating ocean: example of the western Pyrenees, Tectonics, 28, TC4012, doi:10.1029/2008TC002406, 2009.

Julivert, M.: Decollement tectonics in the Hercynian Cordillera of NW Spain, Am. J. Sci., 270, 1-29, 1971.

Lagabrielle, Y., Labaume, P., and de Saint Blanquat, M.: Mantle exhumation, crustal denudation, and gravity tectonics during Cretaceous rifting in the Pyrenean realm (SW Europe): Insights from the geological setting of the lherzolite bodies, Tectonics, 29, TC4012, doi:10.1029/2009TC002588, 2010.

Lanaja, J. M.: Contribución de la exploración petrolífera al conocimiento de la Geología de España, IGME, Madrid, 465 pp., 1987.

Laubscher, H. P.. Die Sudostecke des Rheingrabens-ein kinematisches und dynamisches problem, Eclogae Geol. Helv., 75, 101116, 1982.

Le Pichon, X., Bonnin, J., and Sibuet, J.-C.: La faille nordpyrénéenne: Faille transformante liée à l'ouverture du golfe de Gascogne, CR Acad. Sci., 271, 1941-1944, 1970.

Lepvrier, C. and Martínez-García, E.: Fault development and stress evolution of the post-Hercynian Asturian Basin (Asturias and Cantabria, northwestern Spain), Tectonophysics, 184, 345-356, doi:10.1016/0040-1951(90)90447-G, 1990.

Liesa, C. L. and Simón-Gómez, J. L.: A probabilistic approach for identifying independent remote compressions in an intraplate region: the Iberian Chain (Spain), Math. Geol., 39, 337-348, doi:10.1007/s11004-007-9084-x, 2007.

López-Fernández, C., Pulgar, J. A., González-Cortina, J. M., Gallart, J., Díaz, J., and Ruiz, M.: Actividad sísmica en el Noroeste del a Península Ibérica observada por la red sísmica local del Proyecto GASPI (1999-2002), Trabajos de Geología, 24, 91106, 2004.

Luján, M., Storti, F., Balanyá, J. C., Crespo-Blanc, A., and Rossetti, F.: Role of décollement material with different rheologi- cal properties in the structure of the Aljibe thrust imbricate (Flysch Trough, Gibraltar Arc): an analogue modelling approach, J. Struct. Geol., 25, 867-881, doi:10.1016/S0191-8141(02)00087$1,2003$.

Malagón, J., Hernáiz, P. P., Rodríguez Cañas, C., and Serrano, A.: Notas sobre la inversión tectónica y aloctonia de la cuenca VascoCantábrica, Geogaceta, 15, 139-142, 1994.

Martín-González, F. and Heredia, N.: Complex tectonic and tectonostratigraphic evolution of an Alpine foreland basin: The western Duero Basin and the related Tertiary depressions of the NW Iberian Peninsula, Tectonophysics, 502, 75-89, doi:10.1016/j.tecto.2010.03.002, 2011.

Martínez-Torres, L. M.: Corte balanceado de la Sierra Cantabria (cabalgamiento de la Cuenca Vasco-Cantábrica sobre la Cuenca del Ebro), Geogaceta, 14, 113-115, 1993.

Muñoz, J. A.: Evolution of a continental collision belt: ECORSPyrenees crustal balanced section, in: Thrust Tectonics, edited by: McClay, K. R., Chapman and Hall, 235-246, 1992.

Muñoz, J. A.: Alpine tectonics I: The Alpine system north of the Beltic Cordillera: The Pyrenees, in: The Geology of Spain, edited by: Gibbons, W. and Moreno, T., Geological Society of London, London, 370-385, 2002.

Muñoz-Jiménez, A. and Casas-Sainz, A. M.: The Rioja Trough (N Spain): tectosedimentary evolution of a symmetric foreland basin, Basin Res., 9, 65-85, doi:10.1046/j.13652117.1997.00031.x, 1997.

Olivet, J. L.: La cinématique de la Plaque Ibérique, Bull. Cent. Rech. Explor. Prod. Elf-Aquit., 20, 131-195, 1996.

Olivè Davò, A., Aguilar Tomás, M., and Ramírez del Pozo, J.: Mapa Geológico de España 1:50.000, Sheet 136 (Oña), IGME, Madrid, 1978.

Pais, J.: The Paleogene and Neogene of Western Iberia (Portugal). A Cenozoic record in the European Atlantic domain, SpringerBriefs in Earth Sciences, New York, 158 pp., 2012.

Pedreira, D., Pulgar, J. A., Gallart, J., and Torné, M.: Threedimensional gravity and magnetic modeling of crustal indentation and wedging in the western Pyrenees-Cantabrian Mountains, J. Geophys. Res., 112, B12405, doi:10.1029/2007JB005021, 2007.

Pérez-Estaún, A., Bastida, F., Alonso, J. L., Marquínez, J., Aller, J., Alvarez-Marrón, J., Marcos, A., and Pulgar, J. A.: A thinskinned tectonics model for an arcuate fold and thrust belt: The Cantabrian Zone (Variscan Ibero-Armorican Arc), Tectonics, 7, 517-537, doi:10.1029/TC007i003p00517, 1988.

Pérez-Estaún, A., Martínez-Catalán, J. R., and Bastida, F.: Crustal thickening and deformation sequence in the footwall to the suture of the Variscan belt of northwest Spain, Tectonophysics, 191, 243-253, doi:10.1016/0040-1951(91)90060-6, 1991.

Portero, J. M., Ramírez del Pozo, J., and Aguilar, M.: Mapa Geológico de España 1:50.000, Sheet 170 (Haro), IGME, Madrid, 1973.

Pujalte, V., Robles, S., and Hernández, J. M.: La sedimentación continental del Grupo Campóo (Malm-Cretácico basal de Cantabria, Burgos y Palencia): testimonio de un reajuste hidrográfico al inicio de una fase rift, Cuadernos de Geología Ibérica, 21, 227-251, 1996.

Pulgar, J., Pérez-Estaún, A., Gallart, J., Alvarez Marrón, J., Gallastegui, J., Alonso, J. L., and ESCIN Group: The ESCIN-2 deep seismic reflection profile: a traverse across the Cantabrian 
Mountains and adjacent Duero Basin, Rev. Soc. Geol. España, 8, 383-394, 1995.

Pulgar, J. A., Gallart, J., Fernández-Viejo, G., Pérez-Estaún, A., and Alvarez-Marrón, J.: Seismic image of the Cantabrian Mountains in the western extension of the Pyrenees from integrated ESCIN reflection and refraction data, Tectonophysics, 264, 1-19, doi:10.1016/S0040-1951(96)00114-X, 1996.

Pulgar, J. A., Alonso, J. L., Espina, R. G., and Marín, J. A.: La deformación alpina en el basamento varisco de la Zona Cantábrica, Trabajos de Geolología, 21, 283-294, 1999.

Quesada, S., Robles, S., and Pujalte, V.: El Jurásico Marino del margen suroccidental de la Cuenca Vasco-Cantábrica y su relación con la exploración de hidrocarburos, Geogaceta, 13, 92-96, 1993.

Quintà, A. and Tavani, S.: The foreland deformation in the south-western Basque-Cantabrian Belt (Spain), Tectonophysics, doi:10.1016/j.tecto.2012.02.015, in press, 2012.

Rat, P.: The Basque-Cantabrian basin between the Iberian and European plates; some facts but still many problems, Revista de la Sociedad Geologica de España, 1, 327-348, 1988.

Riba, O. and Juardo, M. J.: Reflexiones sobre la geología de la parte occidental de la Depresión del Ebro, Acta Geologica Hispanica, 27, 177-193, 1992.

Rives, T., Rawsley, K. D., and Petit, J.-P.: Analogue simulation of natural orthogonal joint set formation in brittle varnish, J. Struct. Geol., 16, 419-429, doi:10.1016/0191-8141(94)90045-0, 1994.

Roca, E., Munoz, J. A., Ferrer, O., and Ellouz, N.: The role of the Bay of Biscay Mesozoic extensional structure in the configuration of the Cantabrian-Pyrenean orogen: constraints from the MARCONI deep seismic reflection survey, Tectonics, 30, TC2001, doi:10.1029/2010TC002735, 2011.

Rosenbaum, G., Lister, G. S., and Duboz, C.: Relative motions of Africa, Iberia and Europe during Alpine orogeny, Tectonophysics, 359, 117-129, doi:10.1016/S0040-1951(02)00442-0, 2002.

Roure, F., Choukroune, P., Berastegui, X., Muñoz, J. A., Villien, A., Matheron, P., Bareyt, M., Seguret, M., Camara, P., and Deramond, J.: Ecors deep seismic data and balanced cross sections: Geometric constraints on the evolution of the Pyrenees, Tectonics, 8, 41-50, doi:10.1029/TC008i001p00041, 1989.

Santanach, P.: Las cuencas terciarias Gallegas en la termianción occidental de los relieves pirenáicos, Cuad. Lab. Xeol. Laxe, 19, 57-71, 1994.

Santiesteban, J. I., Mediavilla, R., Martín-Serrano, A., and Dabrio, C. J.: The Duero Basin: a general overview, in: Tertiary basins of Spain: the stratigraphic record of crustal kinematics, edited by: Friend, P. F. and Dabrio, C. J., Cambridge University Press, 183-187, 1996.

Serrano, A., Hernáiz, P. P., Magalón, J., and Rodríguez-Cañas, C.: Tectónica distensiva y halocinesis en el margen SO de la cuenca Vasco-Cantábrica, Geogaceta, 15, 131-134, 1994.

Sibuet, J. C., Srivastava, S. P., and Spakman, W.: Pyrenean orogeny and plate kinematics, J. Geophys. Res., 109, B08104, doi:10.1029/2003JB002514, 2004.

Sibuet, J. C., Srivastava, S. P., and Manatschal, G.: Exhumed mantle-forming transitional crust in the Newfoundland-Iberia rift and associated magnetic anomalies, J. Geophys. Res., 112, B06105, doi:10.1029/2005JB003856, 2007.
Srivastava, S. P., Schouten, H., Roest, W. R., Klitgord, K. D., Kovacs, L. C., Verhoef, J., and Macnab, R.: Iberian plate kinematics: a jumping plate boundary between Eurasia and Africa, Nature, 344, 756-759, doi:10.1038/344756a0, 1990.

Srivastava, S. P., Sibuet, J. C., Cande, S., Roest, W. R., and Reid, I. D.: Magnetic evidence for slow seafloor spreading during the formation of the Newfoundland and Iberian margins, Earth Planet. Sc. Lett., 182, 61-76, doi:10.1016/S0012821X(00)00231-4, 2000.

Stern, R. J.: Subduction initiation: spontaneous and induced, Earth Planet. Sc. Lett., 226, 275-292, doi:10.1016/j.eps1.2004.08.007, 2004.

Suppe, J.: Geometry and kinematics of fault-bend folding, Am. J. Sci., 283, 684-721, doi:10.2475/ajs.283.7.684, 1983.

Suppe, J. and Medwedeff, D. A.: Geometry and kinematics of faultpropagation folding, Ecoglae Geologicae Helvetiae, 83, 409454, 1990.

Tavani, S. and Muñoz, J. A.: Mesozoic rifting in the BasqueCantabrian Basin (Spain): Inherited faults, transversal structures and stress perturbation, Terra Nova, 24, 70-76, doi:10.1111/j.1365-3121.2011.01040.x, 2012.

Tavani, S. and Storti, F.: Fault-bend folding as an end-member solution of (double-edge) fault-propagation folding, Terra Nova, 18, 270-275, doi:10.1111/j.1365-3121.2006.00689.x, 2006.

Tavani, S., Quintà, A., and Granado, P.: Cenozoic rightlateral wrench tectonics in the Western Pyrenees (Spain): The Ubierna Fault System, Tectonophysics, 509, 238-253, doi:10.1016/j.tecto.2011.06.013, 2011a.

Tavani, S., Mencos, J., Bausà, J. and Muñoz, J. A.: The fracture pattern of the Sant Corneli Bóixols oblique inversion anticline (Spanish Pyrenees), J. Struct. Geol., 33, 1662-1680, doi:10.1016/j.jsg.2011.08.007, 2011b.

Teixell, A.: Crustal structure and orogenic material budget in the west central Pyrenees, Tectonics, 17, 395-406, doi:10.1029/98TC00561, 1998.

Van der Voo, R.: Paleomagnetic evidence for the rotation of the Iberia peninsula, Tectonophysics, 7, 5-56, 1969.

Vergés, J., Millán, H., Roca, E., Muñoz, J. A., Marzo, M., Cirés, J., den Bezemer, T., Zoetemeijer, R., and Cloetingh, S.: Eastern Pyrenees and related foreland basins: Pre-, syn- and postcollisional crustal-scale cross-sections, Mar. Petrol. Geol., 12, 903-916, doi:10.1016/0264-8172(95)98854-X, 1995.

Vergés, J., Fernández, M., and Martínez, A.: The Pyrenean orogen: pre-, syn-, and post-collisional evolution, in: Reconstruction of the Evolution of the Alpine-Himalayan Orogen, edited by: Rosenbaum, G. and Lister, G. S., Journal of the Virtual Explorer, 8, 57-76, doi:10.3809/jvirtex.2002.00058, 2002.

Vissers, R. L. M. and Meijer, P. Th.: Mesozoic rotation of Iberia: Subduction in the Pyrenees?, Earth-Sci. Rev., 110, 93-110, doi:10.1016/j.earscirev.2011.11.001, 2012.

Wilson, J. T.: Did the Atlantic close and then re-open?, Nature, 211, 676-681, doi:10.1038/211676a0, 1966. 